\title{
Lessons from Comparing the Two Southwests: Southwest China and Northwest New Spain/Southwest United States
}

\author{
Thomas D. Hall \\ Professor Emeritus \\ DePauw University \\ thall@depauw.edu
}

\begin{abstract}
I compare and contrast two "southwestern" frontiers: the southwestern United States, long northeast New Spain (short hand: New Mexico) and southwest China (short hand: Yunnan). Both have been, and even today remain, frontier zones. In the $21^{\text {st }}$ century both are also important borderlands for two of the most important players in the modern world-system, the United States and China. They share a historical orientation to the areas outside of the two states into which they were ultimately incorporated. Both brought a great deal of new practices and ideas into the incorporating states. They serve to give deep historical backgrounds which put discussions of contemporary globalization in perspective. This comparison also makes clear that the concepts of nation-state and precise borders are typically modern and that setting precise borders is a continuing project, even while borderlands remain, like the frontiers that preceded them, frontier zones. These comparisons may also yield insights into world-system expansion and incorporation.
\end{abstract}

Keywords: World-system incorporation, borderlands, frontiers, indigenous peoples, comparative world-systems

In this paper I review some of the understandings of frontiers and borders in a deep historical and global perspective. I seek not only to enhance understanding of frontier processes, but also to begin to sort out what is really new in the $21^{\text {st }}$ century and what is a continuation of older processes, some of which may go back millennia (e.g., Hall and Fenelon 2008, 2009).

A major property of world-systems is that they pulsate, that is, expand and contract, or expand quickly, then slowly (Chase-Dunn and Hall 1997, 2011, 2012). Along these expanding edges a world-system incorporates new territory and sometimes new peoples - at least when they do not flee to hinterlands to avoid state rule. James Scott (2009) describes instances of such flight in detail for Zomia, or highland Southeast Asia, though not in world-system terms. ${ }^{1}$ The

\footnotetext{
${ }^{1}$ There are extensive critiques of Scott (Griesch, 2010; Lieberman 2010; and a series of articles in the Joumal of Global History July 2010). This discussion calls to mind Aguirre Beltran's discussion of Regions of Refuge and Richard White's discussion of "the middle ground." All these types of regions are typically frontiers and share attempts to avoid state rule. Daniel Little (2013) also contributes to this discussion. Sing C. Chew (2013) has an interesting discussion of the development and influence of the first Southeast Asian world-system, and its importance to the development and processes of the growing Afroeurasian world-system.
} 
processes of incorporation are complex and range al ong a continuum from minimal contact to complete peripheralization within a world-system (see Figure 1; Hall 2012 reviews this topic). To some extent incorporation is reversible, but in net tends to be grainy, that is, moving toward increasingly stronger incorporation.

Figure 1: The Continuum of Incorporation

\begin{tabular}{|l|l|l|l|l|}
\hline $\begin{array}{l}\text { Strength of } \\
\text { Incorporation }\end{array}$ & None & Weak & Moderate & Strong \\
\hline $\begin{array}{l}\text { Impact of Core } \\
\text { on Periphery }\end{array}$ & None & Strong & Stronger & Strongest \\
\hline $\begin{array}{l}\text { Impact of Periphery } \\
\text { on Core }\end{array}$ & None & Low & Moderate & Significant \\
\hline $\begin{array}{l}\text { Type of Periphery } \\
\text { World-System }\end{array}$ & $\begin{array}{l}\text { External } \\
\text { Arena }\end{array}$ & $\begin{array}{l}\text { Contact } \\
\text { Periphery }\end{array}$ & $\begin{array}{l}\text { Marginal Periphery or } \\
\text { Region of Refuge }\end{array}$ & $\begin{array}{l}\text { Full-Blown Periphery } \\
\text { or Dependent Periphery }\end{array}$ \\
\hline
\end{tabular}

Source: Kardulias (2010: 59).

Of interest here is that incorporation is a process (or set of processes) that tends to create, modify, transform, and/or eliminate frontiers (Hall 2009, 2012). Incorporation always involves interplay between local individuals and societies with the incorporating world-system. The kind of world-system (its major form of accumulation), kind of state, organization of peoples to be incorporated, and trajectories of change at the time of incorporation all shape the process. The process is usually sporadic, with many changes and occasional reverses. Because incorporation is often only partial, especially in its early phases frontiers are excellent loci in which to study the interplay between the local and larger social structures. In addition to frontiers along the expanding edges of world-systems there are often frontiers between world-system zones - core, periphery, and semiperiphery. Furthermore these processes can take place along any of the world-system boundaries: bulk goods exchanges, political-military ex changes, prestige or luxury goods exchanges, and information/cultural exchanges (Chase-Dunn and Hall 1997, 2011, 2012). A key point here is that such frontiers cannot be explained solely from local processes and events. But equally, neither can they be explained solely from forces and pressures emanating from core regions. Rather, it is the interplay between these two sets of processes. This is one reason why all frontiers seem to have a family resemblance, yet on closer inspection each seems unique. A second point is that boundaries or edges of world-systems are vague. A boundary is where there is a sharp change in the density of networks that constitute the world-system. In this sense mapping of networks may be more appropriate than somewhat arbitrary boundaries.

While this account holds in general, as always, the devil is in the details. One problem is that there little definitive sense of what the range of types of frontiers is, especially if one is examines frontiers anywhere on the globe over the last ten millennia, or even just since the rise of states some five millennia ago. To explore this range - in statistical terms, the universe of frontier - this comparison uses a variance maximizing strategy (Hall 2009). A variance maximizing strategy is an intentional selection of widely different instances of the object under study, in this case, frontiers. The goal is to begin a process of delimiting empirically the range of variation of what is included as exemplars of the object of study. This strategy is most useful 
when the statistical universe - here frontiers - is not well known, which is certainly the case for frontiers over the entire globe over many millennia. A common critique of variance maximizing strategies is that one is comparing apples and oranges. But apples and oranges are fruit, edible, and spherical to name a few similarities. The key point here is that the legitimacy of a comparison is not found in the theoretical point of the comparison, not in the objects being compared. It is only after some sense of the extent of the "statistical universe" is known can more precise and delimited comparisons be made. In a variance maximizing strategy such issues as chronological time, consistency of regional area, types of geography, social structures of resident populations, and so on are, at best, of secondary interest. To be sure, they should become central in later, more refined comparisons. But without knowing the range of variation of what constitutes a frontier, choosing which secondary issues should become central is difficult if not impossible. Hence, in this paper I made a deliberate choice of two widely disparate frontiers. Before turning to more precise description of what a frontier might be, another methodological point needs to be underscored.

World-systems, in addition to pulsation, often exhibit a variety of other cycles (Hall 2012):

- a- or b-phase in Kondratieff cycles [about 50 years]

- rising or falling in hegemonic cycles [about 100 years]

- rising or falling 'long waves' [about 200 years]

- rising or falling Ibn Kaldhun cycles [about 300 years] (Turchin and Hall 2003)

- dark age cycles [about 600 years] (Chew 2001, 2007, 2008).

Because of the existence, or even the possibility, of many different cycles, comparisons must be across parallel phases of cycles, or the comparisons will yield false or misleading conclusions (Hall 2009: 31-32 diagrams such cycles and discusses them in detail; see also Hall, Kardulias, and Chase-Dunn 2011). Thus, comparisons must take into consideration world-system time, that is, comparisons of appropriate phases of cycles. In Patterns of Empire, Julian Go (2011) compares the British and American empires, but not at the same times in chronological history. By carefully delineating hegemonic cycles of (modern) empires, he compares nineteenth-century Britain with twentieth-century United States. While the historical times are nearly a century apart, cyclical phases are the same. This of course is much more difficult in comparing frontiers, since often the cycles are not well known. Still, one must be attentive to potential distortions due to inappropriate comparisons in phases of cycles. It is for these reasons in this comparison that chronological time and length time considered are of secondary importance to variance maximizing.

So what is a frontier?

.... a working definition is a zone, where two different social systems - nonstate societies, state societies, and even world-systems come into more-or-less sustained contact... A frontier is not a border or boundary between two states though that is how the term is used in much of Europe. The term, "borderlands," which refers to a zone on either side of a border or boundary, often is a frontier. Some might argue that transnationalism constitutes a kind of frontier. While that 
suggestion is not without some merit, the term itself means spanning state boundaries, not the zone of overlap between two states (Hall 2009:25-26). ${ }^{2}$

Frontiers are zones or regions that may have changed through space with time. A useful metaphor is frontiers as membranes: membranes have thickness, but appear as lines from a distance; their permeability with respect to direction, what passes through them, the rate of flow (Slatta 1998). They often regulate flows of people and goods that pass through them. Occasionally they are barriers, either to outflow or inflow, but even when delimited by walls they are never entirely effective. In contrast borders are sharp demarcations of boundaries and are typically modern. Their delineation is a continuing project. Typically they are surrounded by borderlands which like frontiers are zones.

How might frontiers be compared? Variations can be spatial, temporal, physiographic, organizational, ethnic - among those already there, new settlers, or both. Also important are type of cycles, phase of cycles, types of boundaries, and conditions of the world-system(s) that shape them. In short, "world-system time" is a major context for comparisons (Go 2011 uses worldsystem time). Is a frontier on the edge of a world-system or internal between states within a core, a periphery, or a semiperiphery, or between these different zones (Chase-Dunn and Hall 1997; Chase-Dunn et al. 2006, 2010; Hall 2006, 2012)? ${ }^{3}$ Finally, frontiers are where incorporation into a world-system occurs. Indeed the incorporation process creates frontiers (Hall 2006, 2012; Carlson 2011, 2012). The implications for empirical and theoretical issues in world-system analyses are discussed after discussions of the frontiers.

One hypothesis might be that modern and ancient frontiers vary with respect to genocide, ethnocide, ethnogenesis, amalgamation, or hybridization. Some frontier processes may be visible only in peripheral and/or frontier areas. Often issues such as these can only be studied from a world-system perspective, but one that examines the system from a local to the system-wide perspective. The comparison of the two Southwests sketched here is an attempt to explore such issues, and to point to the importance of such studies, both for the study of world-system evolution and for understanding contemporary border issues.

The American Southwest has been a frontier with respect to European states since 1542 or so - and much older if one examines inter-polity frontiers among indigenous populations since well before European intrusion. The Yunnan frontier (Yang 2004, 2008, 2011) lasted much longer, from at least two thousand years ago until the present. It was shaped by evolution of various Chinese and other earlier states, by states in Southeast, and to some extent South Asia. This frontier was relatively lightly impacted by European states, and includes multiple frontiers with both state and non-state societies. Both regions have been, and even today remain, frontier zones. In the $21^{\text {st }}$ century both are also important borderlands for two of the most important players in the modern world-system, the United States and China. They share a historical orientation to the areas outside of the two states into which they were ultimately incorporated. Both also brought a great many new practices and ideas into the incorporating states, Yunnan possibly more so than New Spain.

\footnotetext{
${ }^{2}$ Hall (2009) elaborates on this discussion, and cites much earlier work. Also of interest are McCarthy (2008) and Parker $(2002,2006)$. All note that ancient borders and/or frontiers were typically poorly defined. Power and Standen (1999) have edited a useful collection on Eurasian borderlands.

${ }^{3}$ For a discussion of an internal Chinese frontier see Standen (1999). Standen also discusses multiple boundaries (p. $76 \mathrm{ff}$ ).
} 
Indeed, the two areas of northwest New Spain/Southwest United States and what might be called "Greater Yunnan" are part of much larger set of frontiers with changing definitions. ${ }^{4}$ Northern New Spain/Southwest United States is a part of a very large set of Spanish frontiers throughout the Americas. In Contested Ground, Guy and Sheridan (1998a, 1998b) compare and contrast many of these frontiers to elucidate both general and regionally specific aspects of Hispanic frontiers in the Americas. That is not a variance maximizing strategy, but rather a set of close comparisons for which major outside drivers of frontier formation and transformation were much the same because of the dominance of the same imperial power, Spain. That type of comparison serves to highlight local differences precisely because global differences are minimized.

On the other hand Yunnan was one of many different frontiers. Crossley et al. note that "it would be advantageous to set research results side by side - on the oasis frontier of the Northwest, the transmural steppe / sown frontiers of the North, the intra-imperial economic and cultural frontiers of the Southwest, and the coastal frontier of the sands in the Pearl River delta" in the introduction to an edited collection that begins doing just that (2006: 17). As they note for China, so too with the Spanish empire: the various frontiers interacted, sometime directly, more often indirectly through a variety of administrative processes and personnel. More than one observer has noted that frontier administrators rotated not only through the Americas, but into the Philippines, where they referred to local indigenes as "indios" (e.g., Hall 1998).

In comparing these two regions I underscore discussions between Hall $(1989,1998)$ and Yang (2008) that any frontier, especially these two, can only be understood in the contexts of their larger, global interactions, but equally require careful attention to specific local contexts and interactions. To neglect either the local or the global hinders comprehension of complex social interactions. Some of the most neglected topics are the impacts of frontiers on core areas, whether considering the frontier as a whole, or individual frontier locations.

I begin with brief accounts of each region, then turn to a listing of similarities and differences, then focus on comparisons among pre-modern, proto-modern, and modern frontiers. I use these comparisons then to extract some broader lessons and questions about contemporary frontiers and borders.

\section{Southwest China as a Set of Frontiers ${ }^{5}$}

Southwest China, centered more-or-less around what eventually became Yunnan (see Map 1), often included some contiguous areas. It was an amorphous, changing region. Manning (2005: 6) summarizes its history succinctly: "from autonomous region to center of major states to borderland of expanding Chinese dynasties to province within China."

\footnotetext{
${ }^{4}$ I place "Greater Yunnan" within quotes because I am drawing a parallel to the term "the Greater Southwest" (see the maps below) and indicate a shifting region that more-or-less is around modern Yunnan, a point elaborated later in the paper.

${ }^{5}$ This section draws heavily on Bin Yang (2009, 2004, 2011). Also useful were Crossley et al. (2006), Liu (2011), Liu and Shaffer (2007), Manning (2005), and Giersch (2001). Unfortunately Flad and Chen's book (2013) on Central China appeared just at this paper was in final editing stage.
} 


\section{Map 1: Yunnan in the Qing Empire}

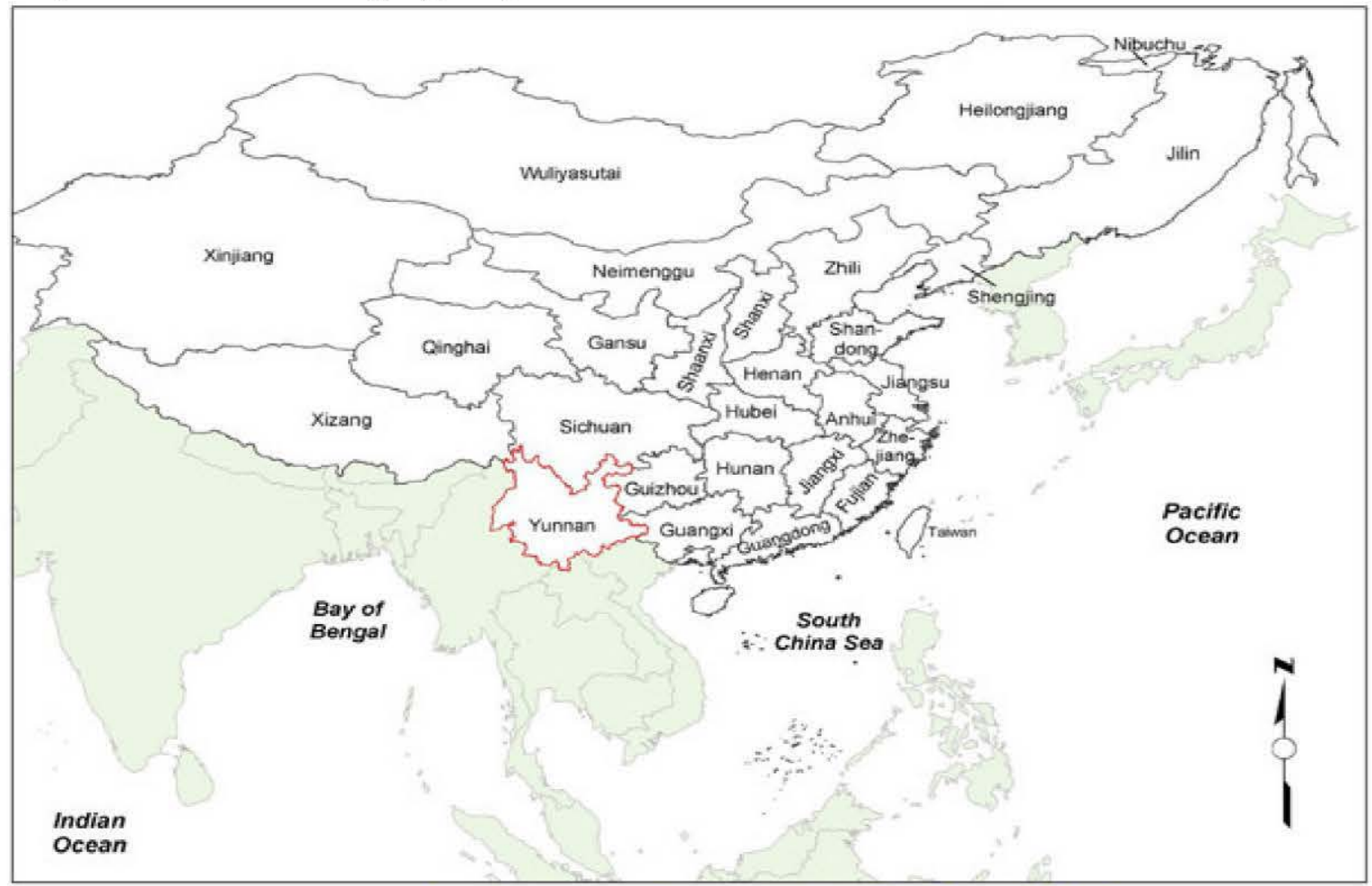

Source: Yang (2008), Map 6.1. (http://www.gutenberg-e.org/vang/detail/map6.1.html)

Yunnan, which means approximately "the land south of the clouds," is an ethnocentric Chinese construct. The region was, and remains, home to several dozen different ethnic groups which in total outnumbered Han Chinese immigrants until just a few centuries ago. General maps of the Silk Roads do not show many of Yunnan's connections (see maps 2, 3, 4, 5). However, Yunnan had many connections to the lands below the winds, that is, Southeast Asia, that were often as strong as or stronger than its connections to China and existed for at least two millennia. Yunnan was connected to what we now know as Tibet, India, and Southeast Asia via a Southwest Silk Road which complemented and supplemented the northern overland Silk Road and the more southerly maritime Silk Road (see Liu 2011; Liu and Shaffer 2007). 
Map 2: The Silk Roads

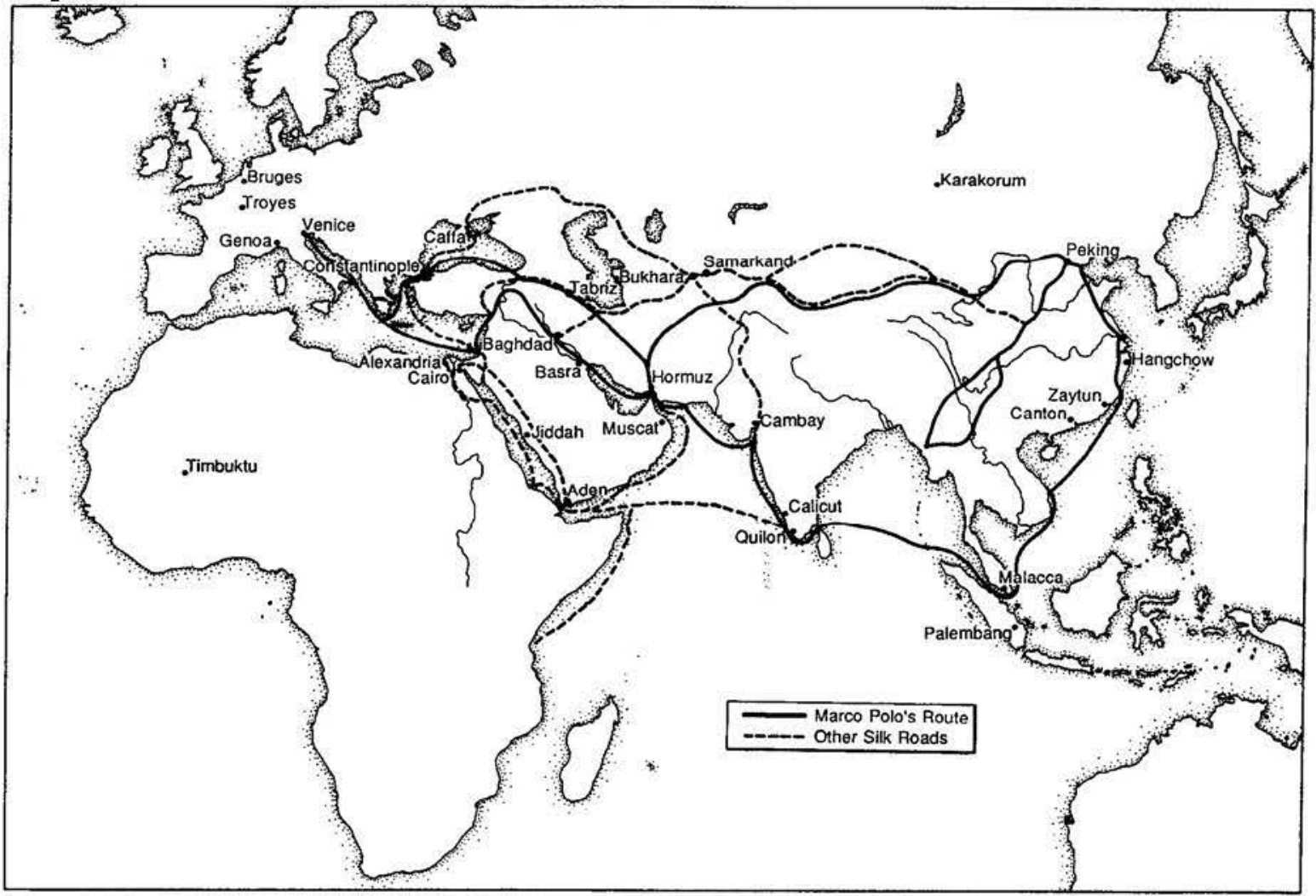

Source: Chase-Dumn and Hall (1997: 165)

The Southwest Silk Road seldom was used to transport silk, but did carry cowries, jade, copper, Buddhist texts, occasionally horses, and other goods. Yunnan was a major source of information to China about Southeast Asia, especially Burma (Myanmar). Several products were very valuable for exchange: copper, silver, horses. ${ }^{6}$ Yunnan is a mountainous and highly varied region, which partially accounts for its ethnic diversity. It has extensive mineral resources. Because of its altitude much of the region is amenable to horse breeding, unlike more tropical areas. Thus, the region often served as an alternative source for horses, especially at times when access to Central Asia pastoralists was closed or difficult. Often it was an alternative to the northern steppe pastoralists as a source of horses or provided areas where steppe horse could be bred. Thus, a dire need for horses tempered the southern Song Dynasty's interactions with Yunnan.

\footnotetext{
${ }^{6}$ China had many sources for horses, but typically did not have access to all of them simultaneously. Yunnan often was a "plan B" source when access to Central Asian sources was curtailed. On the importance of horses to China see, e.g., Beckwith (1991, and especially 2009).
} 
Map 3: Southwest Silk Road Before the $3^{\text {rd }}$ Century BCE

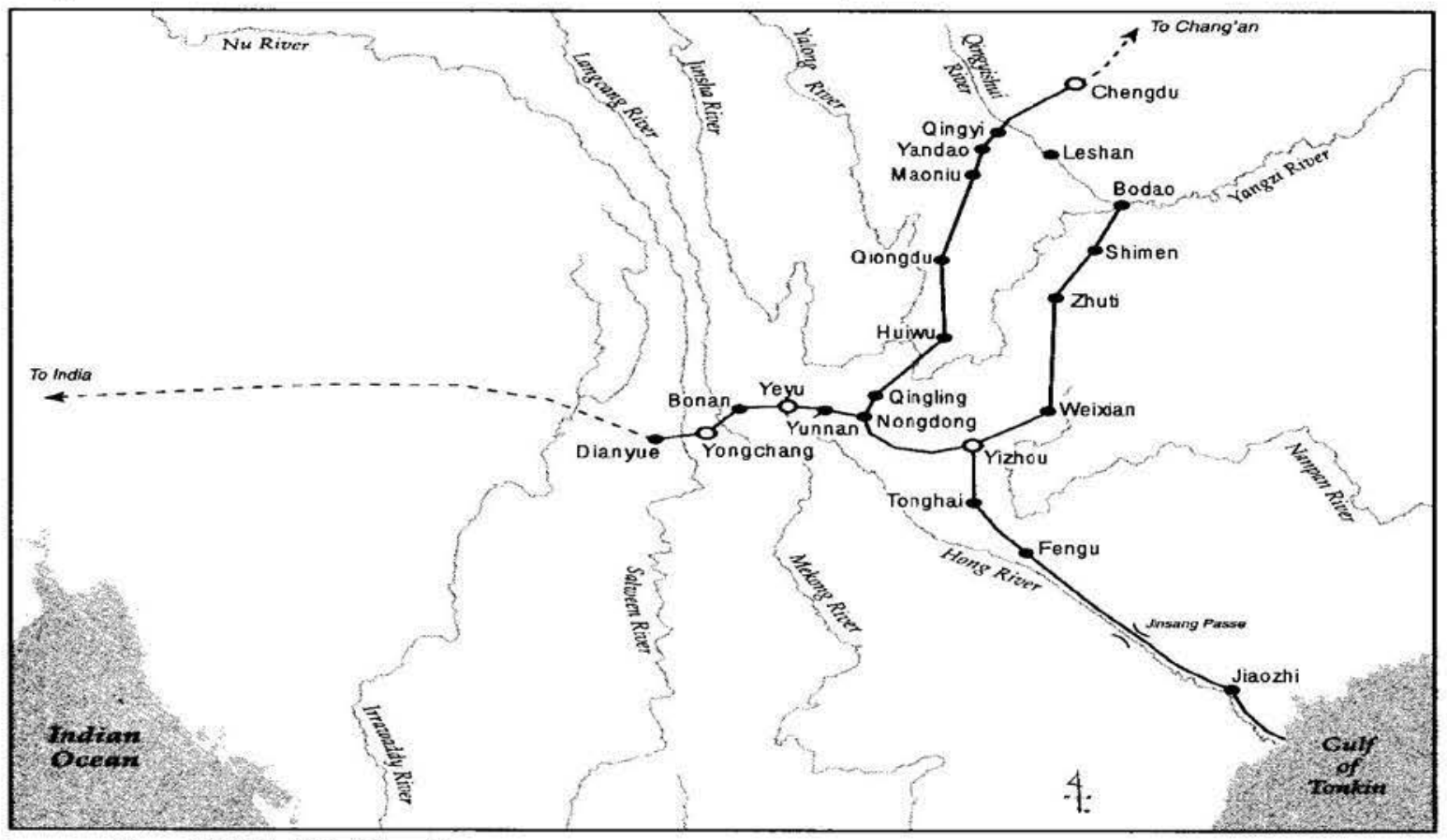

Source: Yang (2004: 291, Map 1).

Map 4: Southwest Silk Road in the Nanzhao-Dali Period ( $7^{\text {th }}$ to mid-13 ${ }^{\text {th }}$ Century CE)

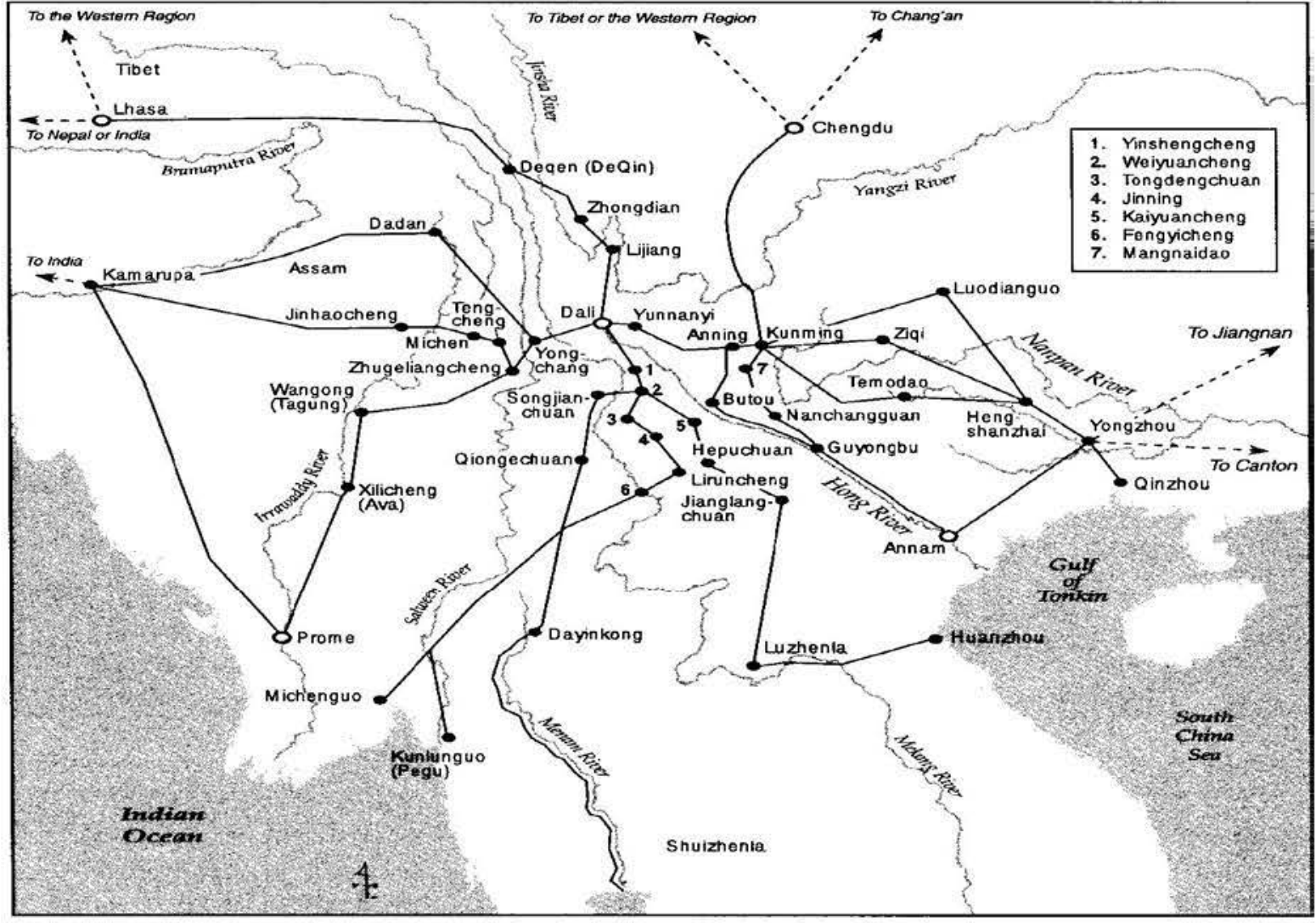

Source: Yang (2004: 292, Map 2). 


\section{Map 5: Southwest Silk Road in the Yuan-Ming-Qing Period (Late $13^{\text {th }}-19^{\text {th }}$ Century CE)}

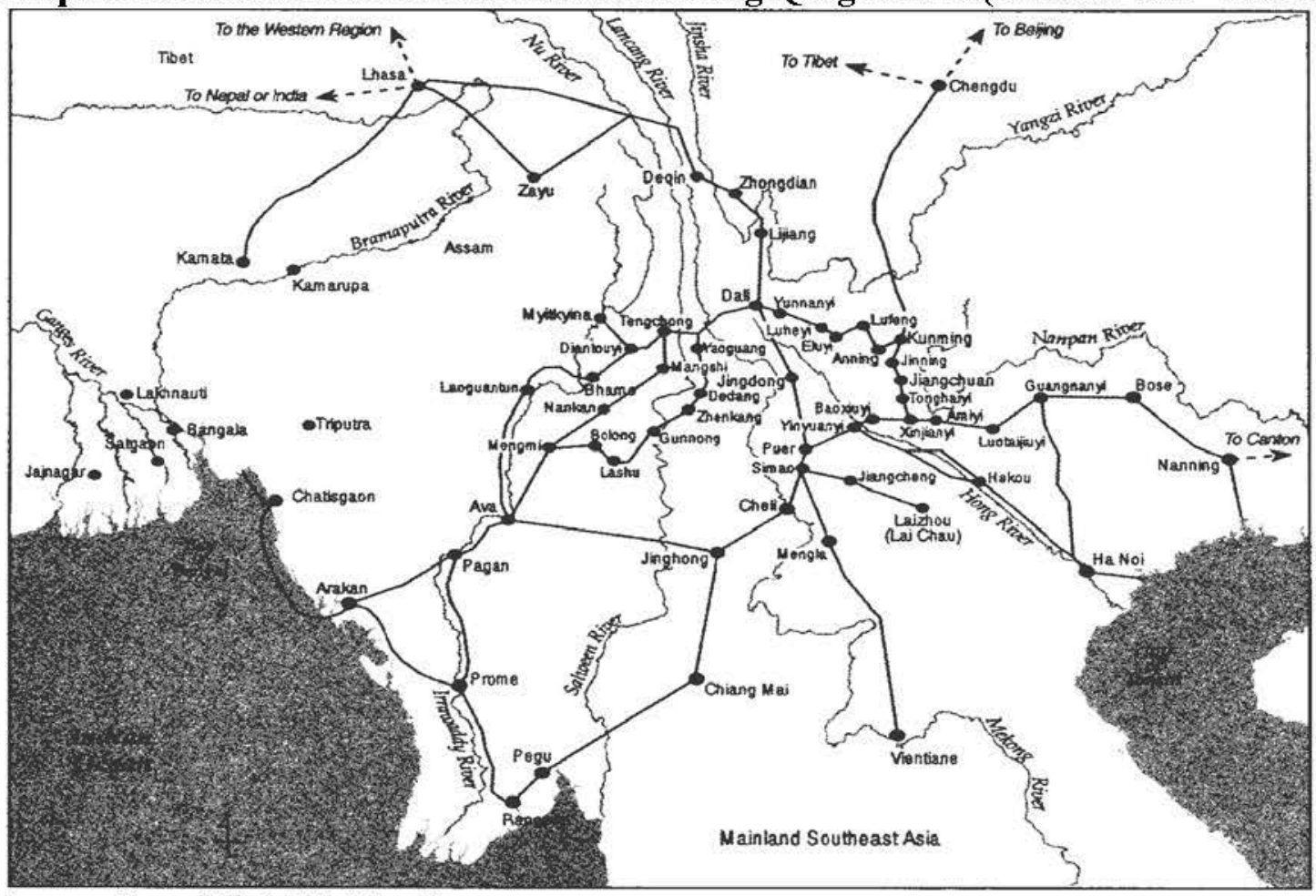

Source: Yang (2004: 293, Map 3).

Prior to the $13^{\text {th }}$ century, various local kingdoms were able to use geographic, climatic, and geopolitical conditions to maintain a degree of autonomy from other states, especially China, and to negotiate, often favorably, the degree and type of incorporation the region experienced. ${ }^{7}$ In lowland areas, the presence of diseases not common in the north killed many invaders (Yang 2010). Mountainous regions presented difficult terrain and at times extremes of cold. During the $2^{\text {nd }}$ and $1^{\text {st }}$ centuries BCE, Han attempts to conquer the region had minimal success and were eventually abandoned because of the much more serious threats from the Xiongnu in the north. After the northern frontier somewhat stabilized, there were further Han forays into Yunnan, but its control was soon weakened with the decline and finally collapse of the empire in the late $2^{\text {nd }}$ century. Serious attempts at conquest did not begin again until the $3^{\text {rd }}$ century during the Three Kingdom period, followed by a few centuries of semi-autonomy for local peoples until their unification under the Nanzhao kingdom in the seventh century. The Nanzhao state maintained considerable autonomy by playing Tang China and Tubo (Tibet) against each other. Early in the $10^{\text {th }}$ century Nanzhao, Tubo, and Tang China collapsed.

The succeeding Ming Dynasty sought stronger control of the region in order to avoid a dependency like the Southern Song had experienced with Yunnan in order to gain access to horses. The Ming sought "to make Yunnan a permanent part of China" (Yang 2008: 95).

Ironically, Yunnan became a part of China as result of the Mongol conquest in 1253 and became part of the Yuan Dynasty. The Mongol conquest was relatively mild because Mongol interest in trade and access to trade routes was more important than territorial expansion per

\footnotetext{
${ }^{7}$ For a discussion of negotiated peripherality, see Kardulias (2007). His analysis is based on ancient Greece and fur trade in North America. It is highly suggestive of questions that might be pursued throughout Greater Yunnan.
} 
se, and because they were unable to penetrate local chieftainships. As long as those goals were met, local rule prevailed.

Up to this time rule was primarily indirect through local, native or indigenous leaders. Yang argues that "Sinicization and indigenization were two sides of the process through which a middle ground was negotiated" (2008: 102). The Chinese had long ruled frontier peoples based on native customs, but with the intentions of "civilizing" (sinicizing) them eventually. This took approximately five centuries in Yunnan; this is a major reason why it is an excellent locale through which to study these processes. Attempts to balance a need for frontier stability, continued sinicization, and the use of indigenous peoples in frontier defense, while clear goals, became messy or even unsuccessful in practice.

The parallel strategies of direct and indirect administrative systems continued through the Mongol Yuan period and extended into the Ming Dynasty. Centralized, province-wide administration was built on governors who were appointed to rule sub-regions. In rural areas that had a preponderance of indigenous populations, native chiefs were placed under the rule of these officials. While local leaders were required to pay tribute and meet other obligations, this did not eliminate continuing interactions including payments to other states in Southeast Asia.

Slowly the Ming and Qing Dynasties adopted the gaitu guiliu policy that sought to transform native chiefs into a part of the imperial administration. Gradually, the domination of ethnicity over administration in the native chief areas changed to a system in which ethnicity became a subdivision of administration. This was facilitated by many imperial regulations and practices, such as regulating the inheritance of chieftainship and taking sons of chiefs to Chinese schools (local or central locations in China) to train them in Chinese language and administrative processes. Upon their return they became agents of sinicization.

This process, however, was not one-sided. Yang argues that sinicization and indigenization were sides of the same coin. They contributed to the emergence of Yunnanese as provincial identity and in turn became an avenue for the absorption of some Yunnanese practices into Chinese identity and culture. Through immigration, settlement of soldiers, and movement of traders, Han people became the largest single ethnic population in Yunnan by the end of the Ming Dynasty. The introduction of Chinese agrarian production was challenged by local climate and topography: "climate, topography, mineral sources, and native economic practices all forced Chinese migrants to adopt native economic structures" (Yang 2008: 164). Thus, a hybrid society developed. Sinicization grew through bureaucratic administration and continued education of sons of local indigenous leaders. Indigenization entailed the introduction of many "barbarian" customs and goods into Chinese culture, such as clothing, dances, chairs, and so on. Local climatic conditions forced changes in Han agricultural practices.

The presence of large mining communities led to types of urbanization different from those in the central provinces. The use of cowries (shell money) in Yunnan continued longer than in any other part of China (Yang 2004, 2011). Gender imbalances in immigration led to extensive intermarriage, which gave traders and others better access to local networks. This was the main path for the introduction of different sexual practices and sexual tools from Yunnan into Chinese culture. All of these changes contributed to the emergence of a distinctive Yunnanese identity. Yang (2008) argues that these changes were also roots of the minzu system (officially recognized minority groups) which is still in operation today: "In essence, the incorporation of Yunnan helped build China as a multiethnic entity" (182). These processes allow a special window into changes in both the meaning and content of "ethnicity" in China. 
Gradually the economy became redirected to China, and there was a slow shift from cowries to copper ${ }^{8}$ as money. Although cowries began to disappear from China about two millennia ago, in Yunnan as late as the Ming Dynasty cowries were used to pay taxes, to pay local salaries, and even used for donations to monasteries. Cowries remained useful for local small scale trade and along the Southwest Silk Road because no single state could implement a currency policy. The long use of cowries was due to Southwest Silk Road trade, but eventually disappeared when Europeans expanded into Southeast Asia and disrupted the supply.

In the Qing Dynasty, immigration to Yunnan increased gradually, no doubt aided by the introduction of New World crops like tomatoes, corn, and sweet potatoes, which opened hilly areas to increased food production. This was driven by and made possible increased urbanization and industrialization, which in turn spurred further increases in food production. The population grew from 5 million in 1700 to 20 million by the mid- $19^{\text {th }}$ century. These shifts helped promote the creation of a Yunnanese identity that has remained somewhat distinct within overall Chinese identity. $^{9}$

Copper mining was the primary force toward industrialization. Reduction of Japanese copper supply heightened interest in Yunnanese copper. While Chinese administrations generally discouraged concentration of miners as potential sources of unrest, they were necessary in Yunnan. Increased copper mining and smelting took a severe toll on local ecology; decline in available charcoal eventually slowed copper production. Yang (2008) argues that the Yunnan frontier had significant impacts on the world-system through its various external links.

Yunnan's many identities contributed to the development of a Chinese multi-ethnic culture. A key shift was from "barbarians" to imperial subjects, to "younger brothers" in larger Chinese ethnicity. In Yunnan ethnic groups were able to maintain a modicum of autonomy, and developed a larger Yunnanese identity which in turn shaped the history of the minzu (ethnic group) system. This is a particularly salient example of how frontier processes and policies can shape national policies.

Clearly, Yunnan has remained a frontier connecting multiple civilizations - China, Southeast Asia, and South Asia.

\section{"The Greater Southwest": A Brief History ${ }^{10}$}

Defining the "Greater Southwest," like defining "Greater Yunnan," is difficult because it is vague and has changed over time. Meinig says:

The Southwest is a distinctive place to the American mind but a somewhat blurred place on American maps, which is to say that everyone knows that there is

\footnotetext{
${ }^{8}$ Silver was so abundant that it was used in many Buddhist statues. By the end of the Ming Dynasty, Yunnan produced seventy-five percent of China's silver, a scale comparable to silver imports from the New World. China came to depend on frontier production.

${ }^{9}$ The distinctiveness of Yunnan, as well as its ethnic diversity, figures prominently in many contemporary travel guides for Yunnan.

${ }^{10}$ This section draws heavily on Hall $(1989,1998)$ and the sources cited therein which document the claims made here. Blackhawk (2006), Brooks (2002), Carter (2009), Hämäläinen (2008), Kessell (2002, 2008), Reséndez (2005), and Weber $(1982,1992)$ were major sources for more recent information.
} 
a Southwest but there is little agreement as to just where it is [...] The term "Southwest" is of course an ethnocentric one: what is south and west to the Anglo-American was long the north of the Hispanic-American. (1971: 3)

Reed facetiously defined the Southwest as reaching from Durango to Durango (Mexico and Colorado) and from Las Vegas to Las Vegas (New Mexico and Nevada; see Map 6) (1964: $175)^{11}$

Map 6: The Greater Southwest

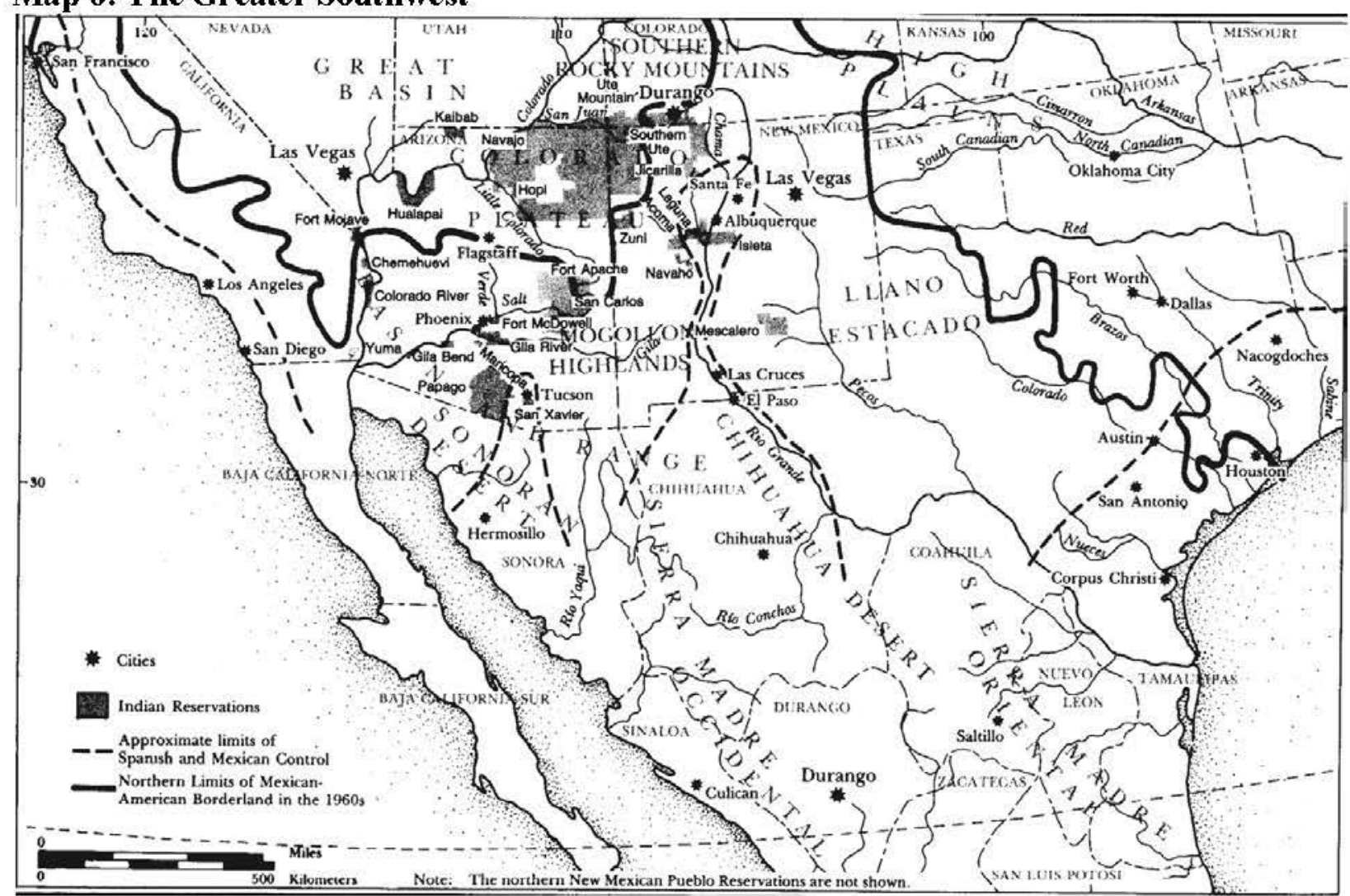

Source: Hall (1989: 35, Map II).

For approximately the first three centuries of European domination, the American Southwest was the northwestern frontier of New Spain. There were two waves of modern incorporation into world-economies: the Spanish-Mexican from the $1530 \mathrm{~s}$ to 1846 ; and the American from 1846 to the present. Spain and the United States offer an opportunity to compare a declining mercantile power with a rising semiperipheral industrial power that eventually became the hegemonic core state. At the regional and local levels there were many indigenous societies, each with its own trajectory of incorporation.

Spaniards entered the area in the 1530s and colonized New Mexico under Oñate in 1598. They did not encounter a large world-system, nor did they find a "new" Mexico, as the rumors of gold and of the seven cities of Cibola had led them to believe. Trade and other connections

\footnotetext{
${ }^{11}$ The first four entries of the Borderlands Sourcebook discuss the definition of the Southwest in detail (Stoddard et al. 1983).
} 
between the Southwest and Mesoamerica had attenuated severely centuries earlier. Social change at the time of Spanish intrusion was toward decreasing social complexity. ${ }^{12}$ Disappointed colonists wanted to leave, but the Viceroy ordered them to stay in New Mexico to pre-empt potential claims by Euorpean rivals and to protect the silver mines far to the south surrounding Zacatecas. ${ }^{13}$ They extracted resources from the horticultural Pueblo societies, treating them as vassal "nations" to the Spanish king, and controlled trade with nomadic groups. ${ }^{14}$ Franciscan friars sought to force Pueblo groups to adopt the Christian faith, and these efforts sometimes were supported by local civil authorities. At other times, when the Friars interfered with economic activities such as the sale of captives, civil authorities undermined missionary efforts. Church and state often worked at cross purposes in the seventeenth and early eighteenth centuries.

Continual lack of state support pushed the military to supplement its pay with booty taken during conflicts. Occasionally obtaining spoils was a major motivator of conflict. The main resources available from nomadic groups were captives to be used as domestic servants or sold to the miners in the south. Horses, and to a lesser extent guns, gradually spread to indigenous peoples, despite Spanish efforts to monopolize both. Again, acquisition of horses and/or guns was a major motivator of indigenous raids. Nomads who wanted horses or guns to defend themselves against raids by rivals had little to trade but captives taken from their own enemies. Raids by an indigenous group on another prompted vengeance by kinsmen, which quickly led to a state of endemic warfare. ${ }^{15}$ Continuous trade in captives, shortage of military resources, and frequent Spanish civil-ecclesiastic bickering reinforced endemic warfare among indigenous groups and between indigenous groups and Spanish settlers. Oppression, both economic and religious, of Puebloan peoples during the seventeenth century led to a rebellion (Pueblo Revolt) in 1680 which drove Spaniards from New Mexico for thirteen years.

Imperial worry about European rivals and Church worry over the few Christianized Indians left behind prompted reconquest and recolonization of New Mexico in 1693. Thereafter many of the same conditions arose again. Societies with fluid social organizations, changing leadership, and vague boundaries do not mesh well with bureaucratic organizations. Logistic problems exacerbated the problems generated by competing lines of authority in New Spain. Policies were influenced by local trade, especially in captives, and by the variations in ecological adaptation of local groups.

The Viceroys of New Spain needed to pacify the frontier, but had limited resources to do so. Endemic warfare was a major obstacle and caused expenditures of scarce funds. Even after the late eighteenth century reorganization of the frontier provinces (Bourbon Reforms), Northern New Spain cost at least 55,000 pesos annually to administer. Efforts to economize shifted pressures onto indigenous groups. Gradually, New Mexican administrators invented new strategies to curtail the fighting. The small Spanish minority maintained control through induced

\footnotetext{
${ }^{12}$ See Carter (2009), Crown and Hurst (2009), Mathiowetz (2011), and Liebman (2012) for recent evidence documenting some of the older connections.

${ }^{13}$ These were vital to the Spanish Empire since the silver mines in north central Mexico produced more wealth than any other silver source in the Americas.

${ }^{14}$ Nomadic does not mean random. It means moving through a known territory, often along well-known paths.

${ }^{15}$ This sort of frontier violence is actually quite common. See Ferguson and Whitehead (1992) and Blackhawk (2006).
} 
dependence on Spanish goods, a divide and conquer approach toward alliances, and pressure on nomadic groups toward political centralization.

Governors tried to settle nomadic groups into compact farming communities in imitation of Spanish villages. This process had worked in central New Spain, but it was not effective on the northern frontiers because of the ready opportunity to flee to hinterlands. Officials designated leaders with whom to negotiate and frequently gave staffs of office, medals, and other insignia to them. This worked better with sedentary groups than with nomadic groups. Pueblos became increasingly symbiotic with Hispanic settlers, a tendency reinforced by the continual threat of nomadic raiders. Often, however, this symbiosis was quite shallow and native cultures went underground. This is how and why in the $21^{\text {st }}$ century many Pueblo religious practices and several indigenous languages persist.

Few nomads were sedentarized effectively, but they did become somewhat more centrally organized; they developed somewhat more institutionalized forms of leadership. This pressure was strongest on Comanche bands (Kavanaugh 1996; Hämäläinen 2008), while an opposing divide and conquer strategy promoted fragmentation of Apache bands.

Comanches, who occupied territory at and beyond the edge of the northern frontier, were able to trade with Plains groups and some Europeans to obtain guns. There are reports, disputed by some scholars, that Comanches brought French flintlocks to the Pecos (New Mexico) trade fairs in the seventeenth century. Settlers eagerly sought such guns to circumvent the official restriction of firearms to the military. Comanches obtained horses in return and also from Apaches and other groups. Comanches quickly became very successful mounted hunters and warriors by capitalizing on their middle position in the horse and gun trade. They developed extensive trade networks of their own and came to dominate the region north and west of the New Mexican frontier (Hämäläinen 1993, 2003, 2008).

New Mexican governor de Anza (1778-1787) repeatedly defeated Comanche bands and banned trade with them, while Texas blocked their trade with Louisiana. In 1785 many Comanches sought peace. Governors de Anza (New Mexico) and Cabello (Texas) required similar conditions: cease hostilities with Spanish subjects; release captives Spaniards; no trade with other Europeans; conformance to Spanish declarations of peace and war; fight against Lipan Apaches; pursuit of Apaches in Coahuila only with Spanish permission; and that all Comanches agree in unison. In return they would receive annuities. A treaty made in April 1787 led to the appointment of Ecueracapa as "captain general" of all Comanches. He was granted an annual salary of 200 pesos, with another 100 pesos for a subordinate chief. ${ }^{16}$ New Mexico would not grant asylum to Comanches who fled tribal law. During a drought a few years later, citizens of Santa Fe supplied food to Comanches, thereby cementing a lasting peace.

Without the treaty New Mexico might not have survived as a province. Comanches became a very effective "border patrol," informing New Mexican officials of movements of other Europeans and buffering the region from raids by other indigenous groups. Comanches also became allies in subduing other indigenous groups, especially Apaches. They wanted no part of an Apache peace. The Comanche bands became the most centralized of the northern nomads, but did not become a permanent unitary organization. Still, there were short-term benefits to Comanche survival: relations with New Mexican Spaniards improved, and

\footnotetext{
${ }^{16}$ Ecueracapa (Leather Jacket) was an important leader of a large Comanche band known as the Buffalo-eaters (Cuchantica or Cuchanec). When he died of wounds received in a campaign against Apaches, a replacement was elected by an encampment of some 4,500 Comanches.
} 
communication and cooperation among the bands increased, which enhanced trading and raiding activities.

Initially Apache groups gained advantage over other groups by early possession of horses. In the $17^{\text {th }}$ and early $18^{\text {th }}$ centuries they had developed semi-permanent villages on the Plains, allowing organization of large war parties. However, they had poor access to guns, because Spanish policy restricted guns to the Spanish army. Later Apaches gave up this village living and gradually were displaced from the Plains by Comanches who had better access to guns. Large horse herds became necessary for fighting, and pushed toward a more nomadic life.

As Apaches were forced southwest from the Plains their raids made trade and communications between the far north and the interior provinces of New Spain more difficult. This prompted Spanish officials to pursue a divide and conquer strategy. Later there were some attempts to regroup some Apache bands into sedentary farmers on establecimientos de paz (peace establishments). Apaches who sought peace also had to help subdue other, hostile Apaches. This approach worked for a few years, but became less effective because seeds, tools, and provisions for supervisory troops were too expensive. Restrictions on movement chafed those on establecimientos de paz. Still, the peace did allow population growth that overshot the carrying capacity of the region, prompting a return to raiding.

Thus, Apache social ecology differed significantly from that of Comanches. Apaches competed directly with Spanish settlers for resources. Their trade was local and typically played one Spanish community against others. Settled Apaches and settlers resented the cost of help given to those recently pacified.

In the late $18^{\text {th }}$ century peace became precarious, but differently for Apaches and Comanches. Apache population decreased during war and increased during peace. Apaches hindered Spanish development. Comanches thrived under the subsequent alliance with New Mexico and supplied necessary goods to the local economy, such as buffalo hides, jerked meat, and captives, and they protected the borders. These differences were rooted in differential access to horses and guns, adaptation to local ecology, and position in regional social ecology.

Slowly the frontier became more tightly incorporated into the Spanish Empire, and became more fully peripheralized. The change was moderate because frontier policy needed to balance competing goals; still there was some development.

When rebellions in New Spain led to Mexican independence (1810-1821), the frontier peace began to unravel further. Raiding increased during the Mexican era. Yet Comanches maintained the peace with New Mexico though they did raid other Mexican provinces. Mexico began to lose control of its northern provinces due to internal political disorder and BritishAmerican rivalry over the West.

With independence, trade opened along the Santa Fe Trail from St. Louis to Santa Fe. This quickly reoriented northern New Mexico toward St. Louis, and away from Chihuahua in the south. Santa Fe became an entrepôt for American goods into Mexico. Many traders married Mexican women in order to gain licenses to trade in Santa Fe. American traders were attractive husbands because of their reputation of treating women better than Mexican men. This, unsurprisingly, stirred considerable resentment among Mexican men.

The American conquest (1846-1848) transformed much of northwest Mexico into a rising capitalist state and unleashed renewed raiding. The old patterns repeated: the use of volunteer fighters with low pay supplemented by booty and captives, instigation of hostilities by locals bent on their own advancement, continued bureaucratic bungling, and the use of local bureaucratic positions as stepping stones to higher office in eastern centers. It seemed like the 
Americans had studied the Spanish archives in order to repeat their mistakes; actually, it was due similar structural conditions.

There were four major differences under American control. First, all territory became part of the national state. Second, the United States had far greater resources to enforce its will, even in remote areas. Third, Americans removed the means of subsistence for nomadic groups, forcing them on to reservations. Fourth, New Mexico and Arizona Territories were primarily a land bridge to California. Once the "bridge" was open there was little need to disturb the region, allowing time and "space" for indigenous groups to adapt to the new situation.

Large numbers of Europeans, most from the United States, poured into Texas and California. Those two states began their climb toward major U.S. population centers. New Mexico no longer was the center of European population in the American Southwest. During the Civil War, New Mexico split into two territories, New Mexico and Arizona, as a result of complex political maneuvering designed to block Confederate access to California ports. These two states remained territories until 1912 primarily because they had such large Hispanic and Indian populations. Indeed, in New Mexico primary speakers of Spanish only became a minority in the $1920 \mathrm{~s}$. It is noteworthy that in the $21^{\text {st }}$ century continued immigration from Mexico and other former Spanish colonies is beginning to reverse these trends.

After annexation by the United States, the continued growth of Santa Fe Trail traffic increased intergroup competition. Incompatible land uses - cattle grazing versus buffalo hunting - strained ecological resources for productive technologies of nomadic groups, leading to intensification of fighting. Many indigenous groups needed to raid European settlements or starve. Attitudes among United States citizens toward Indians exacerbated conditions. They rejected Apache overtures to become allies against Mexicans. Traffic in captives again promoted fighting. The army was an important factor in local economies. Military efforts to "pacify" nomadic groups were helped by a thriving national economy, but slowed by the Civil War (18611865). American actions reversed the trajectories of Comanche and Apache social change.

Comanches blocked westward expansion into Texas, straddled the Santa Fe Trail, and occupied a narrowing no-man's-land between Texas, New Mexico, and northern Mexico. They prospered initially by trading and raiding among these territories, escaping to the unmapped south Plains, but were gradually surrounded. Other groups from the north were pushed further onto the Plains and hunted more intensely. Europeans also hunted on the Plains, severely depleting the buffalo herds, a major Comanche resource. Some of the "Civilized Tribes" were relocated to Indian Territory from the southeastern United States and infringed on eastern Comanche territory. New Mexican livestock operations - first sheep, later cattle - encroached on their western range. Texans blocked movement to the southeast. Apaches blocked movement to the southwest.

The United States attempted to ease the problem by making treaties with several Plains groups at Medicine Lodge Creek in 1867, which defined the first Comanche reservation. The Comanche Indian Agency was poorly funded, and their small cattle herds were raided by other Indians and by neighboring Texans. Comanches responded by raiding in Texas and provoked counter raids by settlers. After the final Comanche battle at Palo Duro Canyon, Texas (1875) they were forced onto a small Fort Sill reservation.

Apaches lived in a large number of small bands scattered over a diverse territory, making their final subjugation complex. That history is difficult to summarize. Unlike Comanches, Apaches had long been a barrier to trade, and had developed a very effective raiding mode of 
production. They did not depend on any one food source and could change targets for raids easily and frequently.

Because of competition with new settlers, military pressure grew. Arizona developed as a "mineral empire." Both miners and Apaches depended on sedentary producers for supplies. Since the public in the east would no longer tolerate the annihilation of Indians, the only alternative was for the government to feed them. But there were insufficient funds to do so. Also, Indian wars became a vital part of the local economy. This difference of opinions about Indian policy is one root of the western opposition to "government interference" from Washington. Some local leaders initiated conflicts to keep the federal funds flowing into their pockets. This ended with Geronimo's surrender in 1886.

After the Civil War, nomadic groups were forced onto reservations, eliminating or severely modifying traditional lifestyles. Nomadism, barter, raiding, and sale of captives could not coexist with more intensive uses of natural resources. Farming, ranching, and mining were seen to use the land "more efficiently" than foraging or gardening. The American state did not tolerate such "inefficient" use of resources - a thinly disguised rationale for seizing Indian territories. Native Americans had two choices: join the lower classes of a capitalist state, or die resisting. Many chose the second option. Only where Americans had no desire for the land did native groups get reservations, where they became "captive nations" and welfare recipients.

Again, pacification had different effects on Comanches and Apaches. First, they had different degrees of ecological and political flexibility. Comanches depended heavily on the buffalo, and intentional destruction of the buffalo herds destroyed their base of adaptation. Apaches had more diverse survival strategies. For Comanches the slight increase in centralization and intense dependence on the buffalo made them more vulnerable to rapid defeat. Apaches could disperse and avoid annihilation. Over centuries, they had become adept at forming new alliances, using multiple survival strategies, and adapting to rapidly changing circumstances. Second, geopolitical location played a role. Comanches blocked expansion and communication across the western United States, as Apaches had done under New Spain. After annexation by the United States, Apaches were mainly a diplomatic nuisance along the new international boundary. Neither group could capitalize on a middleman or buffer role. So both groups were "pacified" and "sedentarized," and the Comanches all but destroyed. ${ }^{17}$ Yet, these changes occurred within a larger context.

In the late $19^{\text {th }}$ century the Dawes Act, also known as the General Allotment Act (1887), "freed surplus" Indian land by forcing Indians on reservations to take up farming, often with allotments that were far too small for the sparsely watered west. Also during the time the government, under direction of Louis Henry Pratt, sought to "kill the Indian, but save the man" with required education in boarding schools that sought to eliminate indigenous languages and cultures. While originally intended as a liberal, humane reform as opposed to outright genocide, this policy was disastrous. One of its major, unintended side effects was to facilitate organization of nationwide Native American associations (Adams 1995; Wilkins 2006).

Incorporation processes were episodic and sporadic, but tended to become stronger. The introduction of horses and guns in the Spanish era made pre-contact practices impossible. The contemporary groupings of indigenous peoples in the Southwest were constructed during this

\footnotetext{
${ }^{17}$ In 1786 the Comanche population was between 20,000 and 30,000. By 1866 the Comanche population was estimated at 4,700 ; by 1882 it was 1,382 . By the early $20^{\text {th }}$ century, the Apache population was 14,873 , whereas Comanches numbered 1,171 . While population data are often problematic, the differences are clear: Comanches suffered much more precipitous losses than Apaches did.
} 
era. The United States completed in a few decades what the Spaniards and Mexicans could not do in centuries: permanent sedentarization of nomadic groups.

Figure 2 provides a graphic display of the variations in degrees of incorporation for Apache groups, Comanche groups, and territories that became New Mexico, California, and Arizona. While there is an overall tendency to tighter incorporation, there is also considerable variation, among both the groups and the territories.

Figure 2: Trajectories of Incorporation for the Greater Southwest

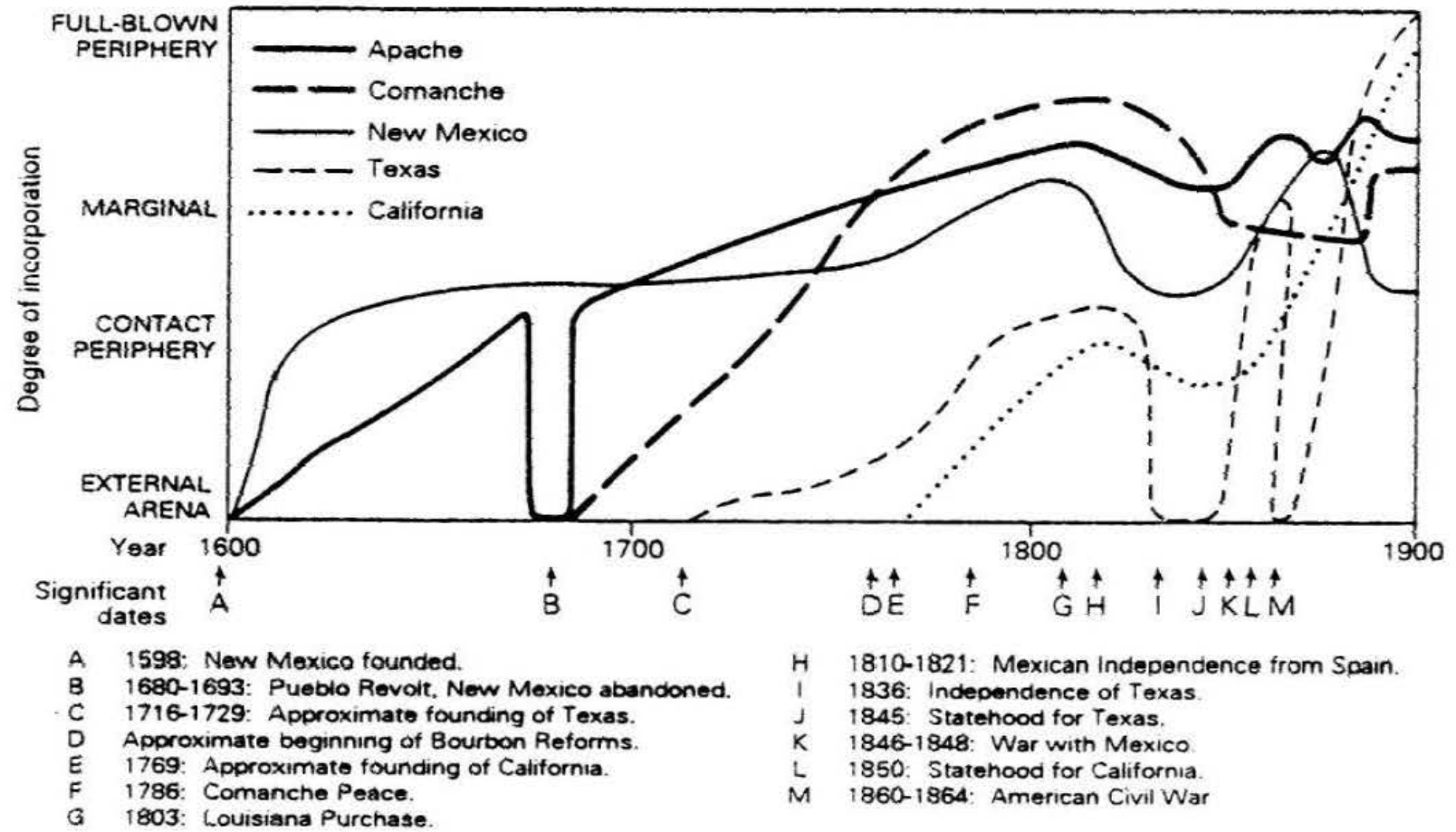

Source: Thomas D. Hall, copyright holder

This example suggests that incorporation into any world-system is problematic: (a) according to the ty pe of sy stem doing the incorporating; (b) with respect to social organization of incorporated groups; (c) with respect to the conditions of the incorporating system; and (d) with respect to a variety of local factors. The degree to which an area or group is incorporated into a world-system defines the context within which local changes may occur. ${ }^{18}$ Local actions are major factors in the costs of incorporation. Incorporation is a matter of degree and is not fully elastic. Sometimes changes engendered by incorporation are difficult or even impossible to reverse, as with the consequences of the spread of horses.

${ }^{18}$ For more detailed explanation of incorporation processes see Hall $(2009,2012)$. A recent comparison of the British and American empires, Pattem of Empire (Go 2011) shows that colonial and administrative policies were heavily shaped by local resistance and conditions. This type of influence remains under-investigated in frontier studies. 
This account shows that incorporation begins with early contact. Second, incorporated groups, even non-state societies, play an active role in the process. ${ }^{19}$ Third, incorporation is variable and sporadic. Finally, more than economic reasons prompt attempts at incorporation.

Before turning to comparisons of the two southwests and some general conclusions about the comparative study of frontiers, Table 1 provides a summary timeline of events discussed above.

Table 1: Timelines for Greater Yunnan, Greater Southwest, and World-System (300 BCE 1990s CE)

\begin{tabular}{|c|c|c|c|c|c|}
\hline Period & Yunnan & US Southwest & $\begin{array}{c}\text { World-System } \\
\text { Conditions }\end{array}$ & $\begin{array}{l}\text { Other (Boswell and } \\
\text { Chase-Dunn 2000) }\end{array}$ & $\begin{array}{l}\text { Epi/pandemics } \\
\text { (Chew 2008) }\end{array}$ \\
\hline $\begin{array}{c}\text { ca } 300 \\
\text { BCE }\end{array}$ & Frontier forms & $\begin{array}{c}\text { Only Native } \\
\text { American frontiers }\end{array}$ & $\begin{array}{c}\text { Tributary world- } \\
\text { systems }\end{array}$ & $\begin{array}{c}\text { 3854-2400 BCE } \\
\text { Dark Age } 1 \text { (Chew } \\
2007: 54)\end{array}$ & \\
\hline $\begin{array}{l}2^{\text {nd }} \& 1^{\text {st }} \\
\text { century } \\
\text { BCE }\end{array}$ & $\begin{array}{l}\text { Han attempt, then } \\
\text { abandon conquest }\end{array}$ & & & $\begin{array}{c}\text { Threats from } \\
\text { Xiongnu; } \\
\text { 2402-594 BCE Dark } \\
\text { Age } 2 \\
\end{array}$ & \\
\hline $\begin{array}{c}3^{\text {rd }} \\
\text { century } \\
\text { CE }\end{array}$ & $\begin{array}{l}\text { Three Kingdoms } \\
\text { conquered }\end{array}$ & & $\begin{array}{c}\text { 0-200 A phase } \\
\text { (Chew 2001: 113) }\end{array}$ & & $\begin{array}{l}\text { Smallpox in Rome } \\
\left(2^{\text {nd }} \text { century }\right) ; \\
\text { China }\left(2^{\text {nd }}\right. \\
\text { century })\end{array}$ \\
\hline $\begin{array}{c}\text { ca } 600 \\
\text { CE }\end{array}$ & $\begin{array}{l}\text { Nanzhao } \\
\text { unification }\end{array}$ & & $200-450 \mathrm{~B}$ phase & $\begin{array}{l}\text { plagues throughout } \\
\text { Eurasia; } \\
1188 \text { BCE-689 CE } \\
\text { Dark Age }\end{array}$ & $\begin{array}{l}\text { Bubonic plague in } \\
\text { Europe, Arab } \\
\text { world, North } \\
\text { Africa; Smallpox } \\
\text { in India } \\
\end{array}$ \\
\hline $\begin{array}{c}\text { ca } 900 \\
\text { CE }\end{array}$ & & $\begin{array}{l}\text { Weak links to } \\
\text { Mesoamerica }\end{array}$ & $\begin{array}{l}\text { 450-775 A phase } \\
775-950 \text { A phase }\end{array}$ & $\begin{array}{c}\text { Nanzhao, Tubo, and } \\
\text { Tang China collapse; } \\
\text { 296-1171 CE } \\
\text { Dark Age }\end{array}$ & Smallpox in India \\
\hline $1253 \mathrm{CE}$ & Mongol conquest & & $950-1200$ A phase & & \\
\hline $\begin{array}{c}\text { ca 1200- } \\
1500\end{array}$ & & $\begin{array}{l}\text { Declining } \\
\text { complexity }\end{array}$ & $1200-1500 \mathrm{~B}$ phase & $\begin{array}{c}\text { 1311-1733 } \\
\text { Dark Age }\end{array}$ & Bubonic plague \\
\hline $\begin{array}{c}\text { ca } 1450- \\
1640\end{array}$ & & & $\begin{array}{l}\text { Capitalist world- } \\
\text { system in Europe, } \\
\text { mercantile phase }\end{array}$ & $\begin{array}{c}1496 \mathrm{~B} ; 1509 \mathrm{~A} ; \\
\text { Portugal is hegemon; } \\
1529 \mathrm{~B} ; 1539 \mathrm{~A} ; \\
\text { Hapsburg is } \\
\text { hegemon }\end{array}$ & $\begin{array}{c}\text { Smallpox in } \\
\text { Americas through } \\
1800\end{array}$ \\
\hline ca 1542 & & $\begin{array}{l}\text { Spanish enter the } \\
\text { Southwest }\end{array}$ & & & \\
\hline 1598 & & $\begin{array}{c}\text { New Mexico } \\
\text { colonized }\end{array}$ & & $\begin{array}{c}1559 \mathrm{~B} ; 1575 \mathrm{~A} ; \\
1595 \mathrm{~A} \text {; Netherlands } \\
\text { is hegemon }\end{array}$ & \\
\hline $1600 s$ & $\begin{array}{c}75 \% \text { copper } \\
\text { production for } \\
\text { China; Han become } \\
\text { majority }\end{array}$ & $\begin{array}{l}\text { Pueblo Revolt, } \\
1680-1693\end{array}$ & $\begin{array}{c}1500-1700 \mathrm{~B} \text { phase } \\
\text { OR } 1689 \mathrm{~A}\end{array}$ & $\begin{array}{c}\text { Cowrie use declines; } \\
1595 \mathrm{~B} ; 1621 \mathrm{~A} ; \\
1650 \mathrm{~B} ; \text { Netherlands } \\
\text { is hegemon }\end{array}$ & \\
\hline
\end{tabular}

${ }^{19}$ The ways in which incorporated peoples resist incorporation and the degree to which they can negotiate the terms of incorporation has come to be more widely studied, and has been found to be very wide-spread for any type of world-system (Kardulias 2007). 


\begin{tabular}{|c|c|c|c|c|c|}
\hline $\begin{array}{l}\text { late } 18^{\text {th }} \\
\text { century }\end{array}$ & & Bourbon Reform & & $\begin{array}{c}\text { Dark Age ends 1733; } \\
1720 \mathrm{~B} ; 1747 \mathrm{~A} \\
1762 \mathrm{~B} ; 1790 \mathrm{~A}\end{array}$ & \\
\hline 1821 & & $\begin{array}{c}\text { Mexican } \\
\text { Independence; open } \\
\text { Santa Fe Trail }\end{array}$ & $\begin{array}{l}\text { Capitalist world- } \\
\text { system in Europe, } \\
\text { industrial phase }\end{array}$ & $1814 \mathrm{~B}$ & $\begin{array}{c}\text { Cholera in } \\
\text { Afroeurasia } \\
\text { throughout } 19^{\text {th }} \\
\text { century } \\
\end{array}$ \\
\hline $1846-48$ & & $\begin{array}{l}\text { US-Mexico war; } \\
\text { Southwest annexed } \\
\text { to US; Texas } \\
\text { statehood } 1845\end{array}$ & & $\begin{array}{c}1848 \mathrm{~A} \text {; UK is } \\
\text { hegemon }\end{array}$ & \\
\hline $1850 \mathrm{~s}$ & $\begin{array}{c}\text { Muslin Rebellion } \\
1856-1873\end{array}$ & $\begin{array}{c}\text { California } \\
\text { statehood } 1850\end{array}$ & & $\begin{array}{c}\text { U.S. [re]opens Japan } \\
\text { to trade; Meiji } \\
\text { restoration } 1868\end{array}$ & \\
\hline 1875 & Muslin Rebellion & $\begin{array}{l}\text { Defeat of } \\
\text { Comanches }\end{array}$ & $\begin{array}{l}1^{\text {st }} \text { wave of } \\
\text { globalization }\end{array}$ & $\begin{array}{c}\text { U.S. becomes } \\
\text { semiperiphery; } \\
1872 \mathrm{~B} \\
\end{array}$ & \\
\hline 1886 & & $\begin{array}{l}\text { Geronimo } \\
\text { surrenders }\end{array}$ & & $1893 \mathrm{~A}$ & \\
\hline 1918-19 & $\begin{array}{l}\text { Yunnan-Annam } \\
\text { Railway (1910) }\end{array}$ & $\begin{array}{l}\text { New Mexico and } \\
\text { Arizona statehood } \\
1912\end{array}$ & & $\begin{array}{l}1917 \mathrm{~B} ; 1940 \mathrm{~A} ; \\
1914-1918 \mathrm{WWI}\end{array}$ & $\begin{array}{c}\text { Influenza, global; } \\
\text { Bubonic plague, } \\
\text { Southeast Asia }\end{array}$ \\
\hline $1940 s$ & 1949 PRC & & & $\begin{array}{l}\text { 1939-1945 WWII; } \\
\text { US is hegemon }\end{array}$ & \\
\hline 1970 & & & $\begin{array}{l}2^{\text {nd }} \text { wave of } \\
\text { globalization }\end{array}$ & $\begin{array}{c}1969 \mathrm{~B} ; \mathrm{US} \\
\text { hegemonic decline } \\
\text { begins }\end{array}$ & \\
\hline $1990 s$ & Tourism up & Tourism up & & & \\
\hline
\end{tabular}

Source: Thomas D. Hall

\section{The Two Southwests: Similarities and Differences}

Some key similarities between the two regions are that both supplied valuable goods and avenues of trade to other areas for other goods. Both have highly variegated topography. Both have a high density of indigenous, non-state peoples. Both were avenues for the penetration of new ideologies in the form of religions: Buddhism in Asia, Christianity in the Americas. Both, for considerable time - at least two millennia in the case of Yunnan, four centuries in the Southwest - were nodes on important routes connecting to other areas. Yunnan was a key node on the Southwest Silk Road that had links with the northern, land-based Silk Road, and the southern, maritime Silk Road. New Mexico connected to New Spain/Mexico via Camino Real to Chihuahua and Vera Cruz, later to the United States via the Santa Fe Trail, and to California via the Old Spanish Trail. Both regions underwent considerable identity shifts, albeit very different ones. These processes continue today.

There are some other similarities that seem to be quite common in frontier areas. Traders intermarried with local women to gain better access to local networks. This was officially promoted for soldiers in Yunnan to create both a permanent military presence and to introduce Chinese farming techniques. The latter was often undone by local ecological conditions. All of 
these instances led to the development of hybrid populations, some of which, at least for some time, became distinctive ethnic groups themselves.

For both, the local population was surpassed by immigrants only late in its incorporation process. This actually occurred twice in the American Southwest: first for Spanish populations versus indigenous populations, and second under the United States for U.S. citizens over descendants of Spanish/Mexican populations and indigenous populations. In Yunnan, Han population surpassed local population only in the Ming Dynasty. Thus, in both regions ethnic diversity has remained quite high, indeed the highest in both China and United States. And in both the Southwest United States, especially New Mexico and Arizona (old New Mexico province), and Yunnan this ethnic diversity has become a tourist attraction in itself, actively promoted by local governments. In the United States the presence of Indian owned casinos has added to that draw. With reservations in the United States and the minzu system in China, surviving ethnic groups have maintained a modicum of autonomy. Also in both areas some indigenous individuals were trained in schools run by the dominant state as agents of assimilation and acculturation. It seems that this was more effective and less brutal in China than the United States, but much more detailed research is needed to substantiate such a claim.

There are also key differences. Most obvious is the much longer timeline of the Yunnan frontier/borderlands. Connections to neighboring states also differ considerably. New Mexico connected to French colonies (in what became Louisiana), to the United States, and after the war with Mexico, to Mexico itself. Yunnan, via many branches of the Southwest Silk Road connected to states in Southeast Asia - Vietnam (Annam), Laos, Thailand, and Burma, to the west and north with Tibet, and to the west and south to South Asia - India, Assam, and Nepal. Over at least the last two millennia, connections between Greater Yunnan and other places shifted considerably, and these connections were more variable than those for the Greater Southwest.

There are differences in types of states involved in incorporation, ranging from some of the least complex states in areas surrounding Greater Yunnan two or more millennia ago to the hegemonic power of the current capitalist world-system (United States) for the U.S. Southwest, and many types in between. A key factor is the power differential - political, military, economic, technological, cultural - between the incorporating state and/or world-system and the societies being incorporated. Also important here are roles of those states in the world-system within which they are embedded - whether they are peripheral, semiperipheral, core, or hegemonic core states. The complexity of these issues precludes detailed analysis here, but a few approximations which might serve as hypotheses for further research include:

a) the larger the power differential, the less room available to negotiate incorporation;

b) state actions will vary with position within their world-system: hegemonic core states have wide latitude, while peripheral states have much less;

c) the greater the cultural differences, the more difficult the interaction - e.g., complex states have difficulty understanding nonstate societies, often seeing them as unorganized "barbarians," when in fact they may be very well organized, but not along the same lines as the states (for examples see Hall and Fenelon 2009);

d) the prevailing ethos differs about whether "barbarians" are to be destroyed or civilized, (even in more recent times where destroying indigenous peoples is generally not approved, though it still occurs); 
e) areas being incorporated that are located between competing states or world-systems might be able to maintain greater local autonomy than those facing only one - typically large - state.

This last condition seems applicable to early Greater Yunnan (late first millennium BCE and early first millennium CE), but from the Mongol Conquest on (1253), it is one large state, sporadically growing in power. Given the longer span of time considered, the situation in Greater Yunnan changed much more than that in the Greater Southwest.

Finally, the indigenous populations were quite different. In the U.S. Southwest the most complex societies were the Pueblo villages and Comanches late in the colonial era; most of the rest were nomadic or semi-nomadic. In Yunnan, there were few foragers or semi-foragers. More common were fairly robust sedentary, agricultural chiefdoms with sufficient military power to offer considerable resistance to the Chinese military.

These comparisons make clear that the concepts of nation-state and precise borders are primarily modern. Even where ancient states, such as China, tried to set precise boundaries or borders, this was more often than not wishful thinking. Often a mapping of networks might be more useful (see Berman 2005 and Mostern 2008 for examples from China). Indeed, Monica Smith (2005) goes so far as to argue that ancient states might be better understood as networks than as bounded territories. She says "our current notions [of boundaries] date to seventeenthcentury Europe [...]," and argues that "in sum, contemporaneity in archaeological and historical maps should be viewed as the hypothesis upon which further research is based, rather than an immutable conclusion about the relationship among sites" $(834 ; 838)$. In short, states expand by taking over new networks and collapse when "networks of interaction are broken" (838). This is why ancient claims - and even some contemporary ones - of precise borders or boundaries should be seen more as wishes than as facts. Their existence is a working hypothesis at best. Thus, setting precise borders is a continuing project even while borderlands remain, like the frontiers that preceded them, frontier zones. ${ }^{20}$

Even though separated by over a millennium, there were similar processes, though the particulars varied immensely. According to Yang:

The power struggles among Han China, the Southern Yue, and the Xiongnu people vividly illustrate how Central Asian frontiers and the Southwestern frontier mutually influenced one another. Indeed, it was because of Han China's expansion into Central Asia and into South China that the Middle Kingdom first noticed and then conquered Yunnan. (2008: 75, emphasis added)

Under Spain the concerns were with French to the east and southeast, the British to the northeast, and vague other Europeans to the west and northwest. In addition to contraband trade, blocking access to the highly productive silver mines in Zacatecas was a major concern. Indeed, these are reasons why New Mexico was maintained as a colony even at considerable expense. Under the

${ }^{20}$ This discussion would benefit from a careful analysis in light of the arguments of Doreen Massey (2005; Anderson 2008) about space and its portrayal. That, however, is beyond the scope of this paper. Daniel Little (2013) also provides an interesting analysis of what place means in world history and how that relates to concepts of nation and region. 
United States the concerns were with Russians to the far northwest (northern California, not Alaska), French to the east and southeast, and British for control of seaports along the west coast of North America. Thus, the processes along any one frontier are influenced by other frontiers.

Yang also points out an important difference on the effects of the frontier regions on the central or core states:

Yunnan silver in the Ming period, copper cash replacing cowry currency during the Ming-Qing transition, and Yunnan copper in the Qing period, collectively demonstrated the central penetration over the frontier on the one hand and the significance of a frontier in the Chinese world-economy on the other hand. Thus, Yunnan's case contrasted with the incorporation of the American southwestern frontier by a modern European world-system, which, as Thomas Hall [1989] has pointed out, greatly influenced the Southwestern frontier but did little to affect the modern world-system. (2008: 232, emphasis added)

This is an important contrast, albeit slightly overstated. There were effects of the Southwest on the now capitalist world-system, albeit considerably lower and more indirect than those of Yunnan on China. By annexing the land from Texas to California, the United States gained secure land routes to the California ports, which gave it a considerable advantage over Europeans in trade with Asia. Indeed, the [re]opening of Japan to trade with Europeans by Commodore Perry in 1853 was a direct attempt to get solid, although rather late, foothold in the trade with Asian countries. That opening, in turn, played a role in the Meiji Restoration (1868) and the rise of Japan as a modern state. While significant, these effects in no way matched the effects of Yunnan, especially the copper and silver trade, and through Yunnan, China's impacts on the emerging global world-system.

However, it remains a somewhat open question whether the roots of these differences lie in the differences between ancient and modern frontiers, or in the relative power of the state with respect to the frontier, or in a combination, or in something else. It is not clear whether the gap in power between China and Yunnan was larger, about the same, or smaller than that between the United States and its Southwest. No doubt for Yunnan the power gap changed many times over its long connections with China and other earlier states. In relative terms, though, it is clear that the Southwest region had far less power than Yunnan.

Bin Yang draws the following comparisons between the Yunnan frontier and the New World Frontier at large (2008: 174). In addition to the longer time span, Yunnan differed in two other aspects. First, the long persistence of the frontier in Yunnan meant that it could use its multicultural and external links, including those to China, to develop its own mechanisms and methods to deal with Chinese colonization. These mechanisms were often quite effective. They illustrate one of the longest periods of "negotiated peripherality" (Kardulias 2007). Yang also draws attention to this being the longest lasting instance of a "middle ground," a concept Richard White (1991) developed to describe the long period interaction in what is now the middle west of the United States. Indeed, Yunnan is an excellent place to explore further the concepts of middle ground and negotiated peripherality through more localized and precise case studies.

Such "middle grounds" may be instances of what Peter Turchin (2006) calls a "metaethnic frontier," a fault line between two metaethnic communities. A metaethnic community is a large, typically the largest, grouping of people with some degree of shared identity, often containing many subdivisions. These include "not only the usual civilizations - 
the Western, Islamic, and Sinic - but also such broad cultural groups as the Celts and TurcoMongolian steppe nomads" (5). So a metaethnic frontier is "an area where an imperial boundary coincides with a fault line between two metaethnic communities" (6). He further argues that methaethnic frontiers between semiperipheral and core areas are "incubators of group solidarity" (asabiya, after Ibn Khaldun) (Turchin 2003, 2011). Metaethnic communities are "typically unified by religious markers; specifically, by belonging to one of the world religions, so this marker became particularly relevant beginning in the Axial Age (800-200 BCE)" (Tuchin 2011: 9). He further notes that "world religions that aimed to integrate diverse ethnic groups first appeared during the Axial Age. They include Zoroastrianism, Hinduism, Buddhism, and later Christianity, Islam, and Tengrism (the religion of Turko-Mongolian nomads), as well as such integrative ideologies without a supernatural content as Confucianism and Stoicism" (2011: 10). Hence, these are areas rife with the possibility of formation of semiperipheral marcher states and ethnogenesis which combines formerly disparate communities.

The sharpness of such frontiers may be intensified if the metaethnic boundary coincides with a sharp geographical boundary. World-systems have two sorts of boundaries: those with other world-systems and those with non-state groups. The same might be said of core-noncore boundaries. What is interesting about semiperipheral areas is that they have both types of boundary or frontier zones, and both are metaethnic. The frontiers with the core area(s) are potentially metaethnic in at least three ways. First, the core is often different ethnically as well as politically. Furthermore, as core-semiperiphy rivalry intensifies, the salience of that frontier will increase and is very likely to become metaethnic if it was not already so. Second, the mode of organization, and possibly technological modes (modes of production in a non-marxian sense) are likely to be different. Third, core elites will typically see the semiperipheral elites as inferior, as "barbarians." Examples are Han views of Yunnan chiefs or American views of Spanish/Mexican elites. Indeed, these differences delayed the admission of both New Mexico and Arizona as states until 1912, and are reviving today in debates about undocumented workers.

Frontiers with peripheral areas are of the second type, between state and non-state peoples. This, too, is metaethnic, first, on the basis of very different political structures. Second, there is the "tribal zone" effect (Ferguson and Whitehead 1992a, 1992b), which intensifies warfare among non-state groups and between them and the incorporating state(s). Third, in such settings raiding and trading are often alternative means for non-state groups to obtain goods originating in states. There is a tendency for both sides to view the other as undifferentiated. Thus states see non-state peoples as barbarians, whereas non-state peoples see members of the state from peas ant, to local administrator, specific city, and the entire state as the same entity.

As frontiers persist knowledge develops on each side. Each side may use such intentional misunderstanding to manipulate relations. This is the stuff of any detailed frontier history, and accounts for why even with a steep metaethnic frontier there can be continued interactions, trade, intermarriage, alliances and so forth across the frontier. ${ }^{21}$ For both types of metaethnic frontiers a critical, and very thorny, issue is: when do these relations build larger and stronger identities and when do they divide? This is part and parcel of frontier ethnopolitics. In the U.S. Southwest the effect occurred in both directions in the fragmentation of Apachean peoples and the amalgamation of Comanche peoples, and of course in the construction of "the American Indian" as an imposed identity. The spread of Buddhism, Taoism, Confucianism, in China, and

\footnotetext{
${ }^{21}$ See Brooks (2002) for detailed examples and Reséndez (2005) for a discussion of how nationality (here we could read as asabiya) is constructed in such situations.
} 
Christianity in the Americas were also factors in building metaethnic identities. Further exploration of these frontier/middle ground/metaethnic boundaries will require many detailed studies of frontier areas, and comparisons among them.

Another difference is the role of disease, especially tropical and sub-tropical diseases, on contact, conquest, and colonization. In the Southwest, as throughout the Americas, European diseases decimated indigenous populations. ${ }^{22}$ In Yunnan it was the opposite; disease and the threat of disease slowed attempts at conquest and colonization. Indeed, the fear of and presence of disease eventually became a marker of Han and non-Han differences as well as a boundary marker for the Yunnan region (Yang 2010).

All three incorporating states - Spain, United States, China - made extensive use of indirect rule and indigenous leaders in governing the frontier regions. China seems to have been much more successful than Spain. It is not entirely clear why this was so. Certainly there is merit to an argument that China was more powerful than Spain relative to the frontier region. But how much of that difference can be attributed to direct overland connection as opposed to transoceanic connection? It is also clear that the United States used indirect rule minimally and for a very short time. ${ }^{23}$

A clear difference is that indirect rule was used for a much longer time in Yunnan, and used in more complex relations, than in northwest New Spain. The tripod system developed by the Mongols became the gaitu guiliu policy that sought to transform native chieftains into a part of the imperial administration during the Ming-Qing transition. Gradually, the domination of ethnicity over administration changed into a system in which ethnicity was a subdivision of administration. This is very different. Part of the explanation lies in the considerably greater power of the indigenous populations in Yunnan and existence of very valuable resources there (e.g., copper and silver). This contrasts with Spanish New Mexico where indirect rule was used primarily with already sedentary, village peoples, with a major exception for Comanches. Under Spain or the United States, indigenous leaders never became part of the national state administration. Indeed, a major theme running through U.S.-Indian relations is the preservation of Indian sovereignty (Wilkins 2006; Hall and Fenelon 2009, Ch. 7).

Finally, Yang (2008: 205-6) asks "But was Yunnan a frontier area, an independent worldsystem, a section of another world-system, or an external area over which the two worldeconomies were contending?" He also notes that "Yunnan belonged to the Indian Ocean economy, at least before the Ming period." My answer to his question would be "all of the above," albeit at different times and for different reasons. The closest to that sort of complication in the Southwest are the debates about the connections to Mesoamerica, which were gone by the time the Spanish arrived. It seems worth contemplating how much of Yunnan's long-lasting (partial) autonomy was due to the ability of local leaders to make use of their position as a contested periphery between early states - China, Southeast Asian states, and South Asia. This is a complex question, but one worth eventually pursuing for its potential insights into how separate world-systems keep separate and how they merge.

What then might we learn from all this for $21^{\text {st }}$ century border issues?

\footnotetext{
${ }^{22}$ There is an extensive literature the role of disease in the Americas. Mann's 1491 (2005) and 1493 (2011) provide very readable summaries of those literatures, the debates, and the authors.

${ }^{23}$ See chapter 5 of Go's Patterns of Empire (2011) where he explains this shift was part and parcel of the various phases of empire growth.
} 


\section{Borders, Frontiers, and World-Systems Analysis}

Humans now are facing an impending crisis, and likely a bifurcation point (Wallerstein 2010, 2011), spurred by political and economic collapse. The processes and results of a bifurcation are not predictable, but we may be able to sketch a "possibility space" of consequences. Other recent developments play into this issue.

First is Sing Chew's work on "dark ages" (2007, 2008) which may be intermediate between complete bifurcation and routine cycles in world-system processes. Chew sketches some insightful comparisons among the onsets of dark ages. While by no means certain, climate change, decline of oil, rise in spills, the potential nuclear disasters like the 2011 Japanese earthquake, and the rise in severe weather suggest that the possibility of the onset of a new dark age cannot be dismissed out of hand.

Glen Kuecker (2007) analyzes how a "perfect storm" of political, economic, demographic, and ecological changes might bring greater destruction to core states than the rest of the world-system. Kuecker and Hall (2011) use the analysis of semiperipheral regions as "seedbeds of change" (Chase-Dunn and Hall 1977, Ch. 5) to argue that peoples living in semiperipheral and especially peripheral areas may have the highest likelihood of surviving a "perfect storm" of collapse. This is because they are typically less embedded in the current system, and because they often have been able to maintain lifeways different from those found in core areas. Chief among these are indigenous peoples, who have preserved lifeways that are the most different from, and often most challenging to, the current world-system (Hall and Fenelon 2008, 2009; Fenelon 2012). Wallerstein (2011) argues:

The so-called forgotten peoples (women, ethnic/racial/religious "minorities," "indigenous" nations, persons of non-heterosexual sexual orientations), as well as those concerned with ecological or peace issues asserted their right to be considered prime actors on an equal level with the historical subjects of the traditional antisystemic movements. (34, emphasis added)

Indigenous peoples are not saviors nor can they be imitated directly. Rather, their practices may be suggestive of alternatives to the current system. How they have preserved maintained differences from neoliberal capitalism may provide clues for developing a new kind of worldsystem.

These issues are closely related to contemporary borders and frontiers. Survivors of major changes have been for millennia most common in frontier regions. But we must not get bogged down in studying repeated, older cycles. Comparison with past frontiers may help us identify what is actually new and what are only permutations of old processes.

The comparison between the U.S. Southwest and Southwest China and studies of indigenous survival suggest that claims that the origins of contemporary troubles are in the modern state or in capitalism are overstated. The fundamental origin of these problems is in states, qua states. Certainly capitalism does drive older processes more strongly, but capitalism per se is not the only problem. Gary Snyder argued: "Grandmother wisdom suspects the men who stay too long talking in the longhouse when they should be mending nets or something. They are up to trouble - inventing the state, most likely" (1990: 64). Long ago ( $7^{\text {th }}$ century CE) Tu Fu wrote (Hinton 1988:101): 
Before Three emperors hatched civilization, people ate their fill and were content.

Someone started knotting ropes, and now we're

mired in the glue and varnish of government.

The remark about knotting ropes refers to a very early form of keeping records. Warren Wagar (1999) suggested possible forms of organization that transcend the state. Some of these processes may well be studied in contemporary border regions. The possibilities of such discoveries and understandings are a fundamental value of continued examinations of border processes.

Variations among frontiers can be spatial, temporal, physiographic, or social organizational: different kinds of native peoples and different sorts of settlers. The context of world-system time is likewise important: type of cycle, phase of cycle, type of boundary, and state of the world-system(s) that are shaping frontiers and that frontiers are influencing. It would also seem reasonable to consider whether the frontier was on the edge of a world-system as opposed to an internal frontier within the system, whether it was at the bulk goods, politicalmilitary, luxury goods or informational edge or along some internal boundary. Internal boundaries could be between states or groups in similar positions within the world-system (e.g., core, periphery, or semiperiphery) or they could be between these different zones. A reasonable working hypothesis would be that these two broad categories of frontiers would exhibit different dynamics. Blackhawk's (2006) study of the fringes of the Southwest frontier focuses on the very edge of the system, whereas Reséndez's (2005) study is concerned with the processes of identity change within the system (when what is now southwestern United States was wrested from Mexican control).

In Colony and Empire William Robbins (1994) examines the American West and argues that far from being an open or free frontier, it was highly constrained by the demands of assorted capitalist enterprises. This, of course, makes sense within a world-systems framework. But it also sheds a different light on the common claim that in Canada the law arrived before the settlers, whereas in the United States the settlers preceded the law, and hence the western U.S. was far more violent than western Canada. Rather, frontier violence served the interests of capital in the United States.

Blackhawk (2006) shows that violence served to "ethnically cleanse" indigenous peoples from the U.S. west. This, in turn can be seen as yet another instance of "war in the tribal zone' (Feguson and Whitehead 1992a, 1992b). Here it interesting that the "war in the tribal zone" effect occurs in both tributary and capitalist world-systems. Thus, as with ecological degradations discussed by Chew (2001), a key component of change is the state, irrespective of its primary mode of accumulation or that of the dominant world-system.

In analogous ways comparisons of modern and ancient frontiers show that genocide, ethnocide, culturicide, ethnogenesis, amalgamation, hybridization, and fractionation are common processes on many different kinds of frontiers. What remains to be studied systematically is how various local, regional, state-level, and world-system conditions and dynamics shape these processes. Again, states seem to be as important as the mode of accumulation and local relations of production in shaping ethnic change.

Finally, the study of frontiers illustrates how much can be learned by the study of peripheral regions and peoples and their roles in system change. Indeed, some of these processes may be visible only in peripheral and/or frontier areas. Frontier areas are also where the consequences of both individual and collective action by subordinated groups is often most 
visible, and at times successful. This then becomes a method to explore how it is that actions and changes in peripheral areas (and semiperipheral areas) play important roles in world-system evolution. The effects of frontiers, in total or for only one specific frontier, on overall system processes and change are topics that need a great deal more research. A key point here is that many if not most of these questions can only be asked from a world-system perspective, even though they must be answered in large part locally.

\section{Acknowledgements}

I thank Bin Yang for sharing many papers with me, and saving me from at least some egregious mistakes about the history of Yunnan. Christopher Chase-Dunn, Sing C. Chew, Glen D. Kuecker, Patrick Manning, Ruth Mostern, and Peter Turchin offered useful comments. I presented an early version of this paper at the XXXV ${ }^{\text {th }}$ Political Economy of the World-System conference (Stony Brook), April 28 - 30, 2011, and longer versions at the Social Science History Association meeting (Boston), November, 2011 and the World History Association meeting (Albuquerque), June 27-30, 2012. I received many useful comments at all of these presentations. I thank Jackie Smith, editor of this journal for encouraging me to submit it for full review. Finally, but not least, I thank the two anonymous reviewers for their useful and insightful comments. My greatest regret is that I could not explore in depth some of the topics they suggested. That, alas, I must pursue in future writings. As always, errors remain my responsibility.

Map 1: Thanks to Columbia University Press for permission to reprint Map 6.1 from Between the Clouds, Bin Yang. Copyright (C) 2008.

Map 2: Thanks to Westview Press for permission to reprint Map 8.3 from Chase-Dunn and Hall (1997).

Maps 3, 4, 5: Thanks to University of Hawai'i Press and Journal of World History for permission to reprint maps from Yang (2004) pp. 291, 292, 293.

Map 6: Thanks to University Press of Kansas for permission to reprint Map III.1 from Hall (1989), pp. 35.

Figure 1: Thanks to William Parker for permission to reprint Figure 3.1 from Kardulias (2010), pp. 59. 


\section{References}

Adams, David W. 1995. Education for Extinction: American Indians and the Boarding School Experience, 1875-1928. Lawrence: University Press of Kansas.

Aguirre Beltran, Gonzalo. 1979 [1967]. Regions of Refuge. Washington, DC: Society for Applied Anthropology, Monograph No. 12. (Originally Regiones de Refugio. Ediciones Especiales, No. 46. Mexico City: Instituto Indigenista Interamericano).

Anderson, Ben. 2008. "Doreen Massey: For Space." Pp. 225-33 in Key Texts in Human Geography, edited by P. Hubbard, G. Valentine, and R. Kitchin. London: Sage.

Beckwith, Christopher I. 1991. "The Impact of the Horse and Silk Trade on the Economies of T'ang China and the Uighur Empire." Journal of the Economic and Social History of the Orient 34: 183-98.

-----. 2009. Empires of the Silk Road: A History of Central Eurasia from the Bronze Age to the Present. Princeton, NJ: Princeton University Press.

Berman, Merrick Lex. 2005. "Boundaries or Networks in Historical GIS: Concepts of Measuring Space and Administrative Geography in Chinese History." Journal of Historical Geography 33: 118-33.

Blackhawk, Ned. 2006. Violence over the Land: Indians and Empires in the Early American West. Cambridge, MA: Harvard University Press.

Boswell, Terry and Christopher Chase-Dunn. 2000. The Spiral of Capitalism and Socialism: The Decline of State Socialism and the Future of the World-System. Boulder, CO: LynneRienner.

Brooks, James F. 2002. Captives and Cousins: Slavery, Kinship, and Community in the Southwest Borderlands. Chapel Hill: University of North Carolina Press.

Carlson, Jon D. 2011. "Externality and Incorporation in the World-System: Abyssinia Anomaly or Palimpsest?" Journal of World-Systems Research 17: 165-98.

-----. 2012. "Externality, Contact Periphery and Incorporation." Pp. 87-96 in Routledge Handbook of World-Systems Analysis, edited by Salvatore J. Babones and Christopher Chase-Dunn. New York: Routledge.

Carter, William B. 2009. Indian Alliances and the Spanish in the Southwest, 750-1750. Norman: University of Oklahoma Press.

Chase-Dunn, Christopher and Thomas D. Hall. 1997. Rise and Demise: Comparing WorldSystems. Boulder, CO: Westview Press.

-----. 2011. "East - West in World-Systems Evolution." Pp. 97-119 in Andre Gunder Frank and Global Development: Visions, Remembrances and Explorations, edited by Patrick Manning and Barry K. Gills. London: Routledge.

-----. 2012. "Global Scale Analysis in Human History." Pp. 185-200 in A Companion to World History, edited by Douglas Northrop. Oxford: Wiley-Blackwell.

Chase-Dunn, Christopher, Daniel Pasciuti, Alexis Alvarez and Thomas D. Hall. 2006. "Growth/Decline Phases and Semiperipheral Development in the Ancient Mesopotamian and Egyptian World-Systems." Pp. 114-38 in Globalization and Global History, edited by Barry K. Gills and William R. Thompson. London: Routledge.

Chase-Dunn, Christopher, Thomas D. Hall, Richard Niemeyer, Alexis Alvarez, Hiroko Inoue, Kirk Lawrence, and Anders Carlson. 2010. "Middlemen and Marcher States in Central Asia and East/West Empire Synchrony." Social Evolution and History 9: 52-79.

Chew, Sing C. 2001. World Ecological Degradation: Accumulation, Urbanization, and Deforestation 3000 B.C. - A. D. 2000. Walnut Creek, CA: Altamira Press. 
-----. 2007. The Recurring Dark Ages: Ecological Stress, Climate Changes, and System Transformation. Lanham, MD: Altamira Press.

-----. 2008. Ecological Futures: What History Can Teach Us. Lanham, MD: AltaMira Press.

-----. 2013. "The Southeast Asian Connection in the First Eurasian World Economy 200 BC - AD 500." Forthcoming in Journal of Globalization Studies.

Crossley, Pamela Kyle, Helen P. Siu, and Donald S. Sutton, eds. 2006. Empire at the Margins: Culture, Ethnicity, and Frontier in Early Modern China. Berkeley: University of California Press.

Crown, Patricia L. and W. Jeffery Hurst. 2009. "Evidence of cacao use in the Prehispanic American Southwest." Proceedings of the National Academy of Science, USA 106(7/Feb.): 2110-13.

Fenelon, James V. 2012. "Indigenous Peoples, Globalization, and Autonomy in World-Systems Analysis." Pp. 304-12 in Routledge Handbook of World-Systems Analysis, edited by Salvatore J. Babones and Christopher Chase-Dunn, 2012. New York: Routledge.

Ferguson, R. Brian, and Neil L. Whitehead, eds. 1992a. War in the Tribal Zone: Expanding States and Indigenous Warfare. Santa Fe, NM: School of American Research Press.

-----. 1992b. "The Violent Edge of Empire." Pp. 1-30 in R. B. Ferguson and N. L. Whitehead, eds. War in the Tribal Zone. Santa Fe, NM: School of American Research Press.

Flad, Rowan K. and Pochan Chen. 2013. Ancient Central China: Centers and Peripheries Along the Yangzi River. New York: Cambridge University Press.

Giersch, Charles Patterson. 2001. "A Motley Throng: Social Changes on Southwest China's Early Modern Frontier, 1700-1880." Journal of Asian Studies 60: 67-94.

Giersch, C. Patterson. 2010. "Across Zomia with merchants, monks, and musk: process geographies, trade networks, and the Inner-East-Southeast Asian borderlands." Journal of Global History 5: 215-39.

Go, Julian. 2011. Patterns of Empire: The British and American Empires, 1688 to the Present. Cambridge: Cambridge University Press.

Guy, Donna J. and Thomas E. Sheridan, eds. 1998a. Contested Ground: Comparative Frontiers on the Northern and Southern Edges of the Spanish Empire. Tucson: University of Arizona Press.

-----. 1998b. "On Frontiers: The Northern and Southern Edges of the Spanish Empire in America." Pp. 150-66 in Contested Ground: Comparative Frontiers on the Northern and Southern Edges of the Spanish Empire, edited by Donna Guy and Thomas Sheridan. Tucson: University of Arizona Press.

Hall, Thomas D. 1989. Social Change in the Southwest, 1350-1880. Lawrence: University Press of Kansas.

1998. "The Rio de La Plata and the Greater Southwest: A View From World-System Theory." Pp. 150-66 in Contested Ground: Comparative Frontiers on the Northern and Southern Edges of the Spanish Empire, edited by Donna Guy and Thomas Sheridan. Tucson: University of Arizona Press.

-----. 2006. "[Re]Periphalization, [Re]Incorporation, Frontiers, and Nonstate Societies: Continuities and Discontinuities in Globalization Processes." Pp. 96-113 in Globalization and Global History, edited by Barry K. Gills and William R. Thompson. London: Routledge.

-----. 2009. "Puzzles in the Comparative Study of Frontiers: Problems, Some Solutions, and Methodological Implications." Journal of World-Systems Research 15: 25-47. 
-----. 2012. "Incorporation into and Merger of World-Systems." Pp. 37-55 in Routledge Handbook of World-Systems Analysis, edited by Salvatore J. Babones and Christopher Chase-Dunn. New York: Routledge.

Hall, Thomas D. and James V. Fenelon. 2008. "Indigenous Movements and Globalization: What is Different? What is the Same?" Globalizations 5: 1-11.

. 2009. Indigenous Peoples and Globalization: Resistance and Revitalization. Boulder, CO: Paradigm Press.

Hämäläinen, Pekka. 1998. "The Western Comanche Trade Center: Rethinking the Plains Indian Trade System." Western Historical Quarterly 29: 485-513.

-----. 2003. "The Rise and Fall of Plains Indians Horse Cultures." Journal of American History 90: 833-62.

-----. 2008. The Comanche Empire. New Haven, CT: Yale University Press.

Hinton, David, ed. and trans. 1988. The Selected Poems of Tu Fu. New York: New Directions.

Kardulias, Nick P. 2007. "Negotiation and Incorporation on the Margins of World-Systems: Examples from Cyprus and North America. Journal of World-Systems Research 13: 5582.

------. 2010. "World-Systems Applications for Understanding the Bronze Age in the Eastern Mediterranean." Pp. 53-80 in Archaic State Interaction: The Eastern Mediterranean in the Bronze Age, edited by William A. Parkinson and Michael L. Galaty. Santa Fe, NM: SAR Press.

Kavanaugh, Thomas K. 1996. Comanche Political History: An Ethnohistorical Perspective 1706-1875. Lincoln: University of Nebraska Press.

Kessell, John. 2002. Spain in the Southwest: A Narrative History of Colonial New Mexico, Arizona, Texas, and California. Norman: University of Oklahoma Press.

-----. 2008. Pueblos, Spaniards, and the Kingdom of New Mexico. Norman: University of Oklahoma Press.

Kuecker, Glen D. 2007. "The Perfect Storm: Catastrophic Collapse in the 21st Century." The International Journal Of Environmental, Cultural, Economic And Social Sustainability 3: $1-10$.

Kuecker, Glen D. and Thomas D. Hall. 2011. "Facing Catastrophic Systemic Collapse: Ideas from Recent Discussions of Resilience, Community, and World-Systems Analysis." Nature and Culture 6: 18-40.

Leibman, Matthew. 2012. "The Rest is History: Devaluing the Recent Past in the Archaeology of the Pueblo Southwest." Pp. 19-44 in Decolonizing Indigenous Histories: Exploring Prehistoric/Colonial Transitions in Archaeology, edited by Maxine Oland, Siobhan M. Hart, and Liam Frink. Tucson: University of Arizona Press.

Lieberman, Victor. 2010. "A zone of refuge in Southeast Asia? Reconceptualizing interior spaces." Journal of Global History 5: 333-46.

Little, Daniel. 2013. "Nation, Region, and Globe: Alternative Definitions of Place in World History." forthcoming in Journal of Globalization Studies.

Liu, Xinru. 2011. "A Silk Road Legacy: The Spread of Buddhism and Islam." Journal of World History 22: 55-81.

Liu, Xinru and Lynda Norene Shaffer. 2007. Connections across Eurasia: Transportation, Communication, and Cultural Exchange on the Silk Roads. New York: McGraw-Hill.

Mann, Charles C. 2005. 1491: New Revelations of the Americas Before Columbus. New York: Alfred A. Knopf. 
-----. 2011. 1493: Uncovering the New World Columbus Created. New York: Alfred A. Knopf.

Manning, Patrick, ed. 2005. World History: Global and Local Interactions. Princeton, NJ: Marcus Wiener.

Massey, Doreen B. 2005. For Space. London: Sage.

Mathiowetz, Michael Dean. 2011. "The Diurnal Path of the Sun: Ideology and Interregional Interaction in Ancient Northwest Mesoamerica and the American Southwest." Ph.D. dissertation, Department of Anthropology, University of California Riverside, Riverside, CA.

McCarthy, Mike. 2008. "Boundaries and the Archaeology of Frontier Zones." Pp. 202-9 in Handbook of Landscape Archaeology, edited by Bruno David and Julian Thomas. Walnut Creek, CA: Left Coast Press.

Meinig, Donald W. 1971. Southwest: Three Peoples in Geographical Change, 1600-1970. London: Oxford University Press.

Mostern, Ruth. 2008. "The Qinling Frontier and the Creation of Imperial Space in Western China." Pp. 78-102 in The Collected Papers of the International Symposium of Plank Roads and Applications of $3 S$ Technology, edited by Feng Suiping, Li Rui, Brian Lees and David Jupp. Xi'an: Shaanxi Jiaoyu chubanshe.

Parker, Bradley J. 2002. "At the Edge of Empire: Conceptualizing Assysria's Annotolian Frontier, ca 700 B.C." Journal of Anthropological Archaeology 21: 371-95.

-----. 2006. "Towards an Understanding of Borderland Processes." American Antiquity 71(1/Jan.): 77-100.

Power, Daniel and Naomi Standen, eds. 1999. Frontiers in Question: Eurasian Borderlands, 700-1700. London: Macmillan.

Reed, Erik K. 1964. "The Greater Southwest." Pp. 175-91 in Prehistoric Man in the New World, edited by Jesse D. Jennings and E. Nordbeck. Chicago: University of Chicago Press.

Reséndez, Andrés. 2005. Changing National Identities at the Frontier: Texas and New Mexico, 1800-1850. Cambridge: Cambridge University Press.

Robbins, William G. 1994. Colony and Empire: The Capitalist Transformation of the American West. Lawrence: University Press of Kansas.

Scott, James. 2009. The Art of Not Being Governed: An Anarchist History of Upland Southeast Asia. New Haven, CT: Yale University Press.

Slatta, Richard W. 1998. "Spanish Colonial Military Strategy and Ideology." Pp. 83-96 in Contested Ground: Comparative Frontiers on the Northern and Southern Edges of the Spanish Empire, edited by Donna Guy and Thomas Sheridan. Tucson: University of Arizona Press.

Smith, Monica L. 2005. "Networks, Territories, and the Cartography of Ancient States." Annals of the Association of American Geographers 95: 832-49.

Snyder, Gary. 1990. The Practice of the Wild: Essays. San Francisco: North Point Press.

Standen, Naomi. 1999. "(re)Constructing the Frontiers of Tenth-Century North China." Pp. 5579 in Frontiers in Question: Eurasian Borderlands, 700-1700, edited by Daniel Power and Naomi Standen. London: Macmillan.

Stoddard, Ellwyn R., Richard L. Nostrand, and Jonathan P. West. 1983. Borderlands Sourcebook: A Guide to the Literature on Northern Mexico and the American Southwest. Norman: University of Oklahoma Press.

Turchin, Peter. 2003. Historical Dynamics: Why States Rise and Fall. Princeton, NJ: Princeton University Press.

-----. 2006. War and Peace and War: The Life Cycles of Imperial Nations. New York: Pi Press. 
-----. 2011. "Warfare and the Evolution of Social Complexity: A Multilevel Selection Approach." Structure and Dynamics 4(3): 1-37. http://escholarship.org/uc/item/7j11945r.

Turchin, Peter and Thomas D. Hall. 2003. "Spatial Synchrony among and within WorldSystems: Insights from Theoretical Ecology." Journal of World-Systems Research 9: 3764.

Wagar, W. Warren. 1999. A Short History of the Future, $3^{\text {rd }}$ ed. Chicago: University of Chicago Press.

Wallerstein, Immanuel. 2010. "Structural Crises." New Left Review 62 (March/April): 133-42.

-----. 2011. "Structural Crisis in the World-System: Where Do We Go from Here?" Monthly Review 62(10/March): 31-39.

Weber, David J. 1982. The Mexican Frontier, 1821-1846. Albuquerque: University of New Mexico Press.

----. 1992. The Spanish Frontier in North America. New Haven, CT: Yale University Press.

White, Richard. 1991. The Middle Ground. Cambridge: Cambridge University Press. Revised edition 2010.

Wilkins, David E. 2006. American Indian Politics and the American Political System, $2^{\text {nd }}$ ed. Lanham, MD: Rowman and Littlefield.

Yang, Bin. 2004. "Horses, Silver, and Cowries: Yunnan in Global Perspective." Journal of World History 15: 281-322.

-----. 2008. Between Winds and Clouds: The Making of Yunnan Second Century BCE to Twentieth Century CE. New York: Columbia University Press. http://www.gutenberge.org/yang/index.html.

-----. 2010. "The Zhang on Chinese Southern Frontiers: Disease Constructions,Environmental Changes, and Imperial Colonization." Bulletin of the History of Medicine 84: 163-92.

-----. 2011. "The Rise and Fall of Cowrie Shells: The Asian Story."Journal of World History 22: $1-25$. 